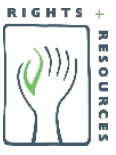

RIGHTS AND RESOURCES INITIATIVE | NOVEMBER 2020

\title{
Rights-Based Conservation: The path to preserving Earth's biological and cultural diversity?
}

Technical Report 


\section{Contents}

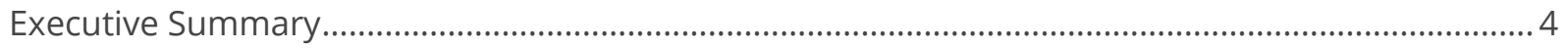

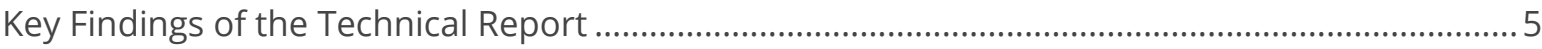

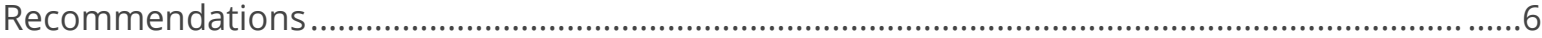

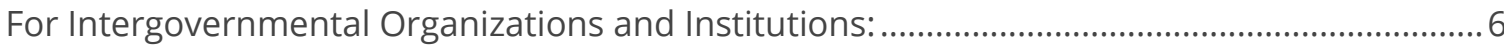

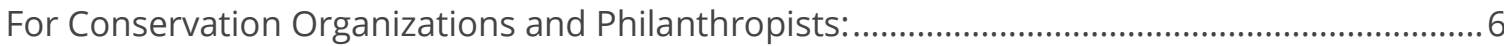

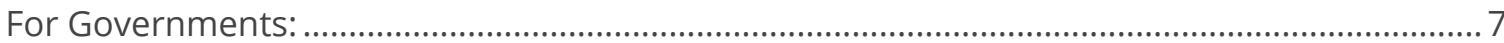

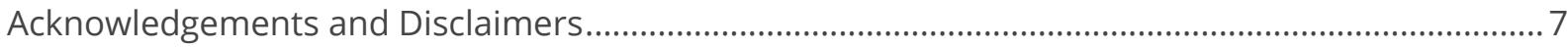

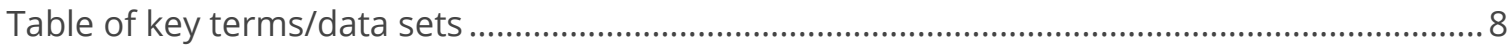

Community rights-based conservation: Recognizing Indigenous Peoples, local communities, and Afro-descendants' rights to achieve conservation targets ..................................................................10

Finding 1: The population of IPS, LCS, and ADs living in important biodiversity conservation areas ranges between 1.65 billion to 1.87 billion people

Figure 1: Human populations living within the "minimum land area" required to conserve terrestrial biodiversity

Figure 2: Human populations living within the "minimum land area" required to conserve terrestrial biodiversity, highlighting existing protected areas

Table 1: People living across important biodiversity conservation areas.

Table 2: Combining important biodiversity conservation areas to achieve spatial targets......14

Figure 3: The proportion of a country's human population living within the "minimum land area" required to conserve terrestrial biodiversity

Finding 2: A greater proportion of people living in important biodiversity conservation areas are in low and middle-income countries and may be placed at risk if exclusionary practices are used to expand conservation

Figure 4: Distribution of people living within important conservation areas by income status.

Table 3: Population density of important biodiversity conservation areas across respective income statuses

Figure 5: People vs Area as a proportion of country within scenario 1; the minimum land area for conserving biodiversity

Box 1: Non-timber forest products in India are essential to the economy and wellbeing of millions of people

Finding 3: Expanding conservation areas by using historically dominant models of exclusionary conservation would be highly contentious, prohibitively expensive and come with human rights costs that will fuel land conflicts

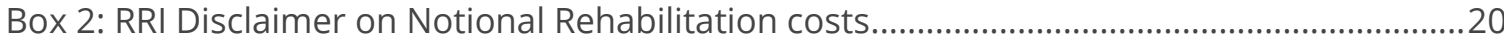

Table 4: The notional cost of compensating people living within conservation priority areas

Finding 4: IPs, LCs, and ADs conserve forests, ecosystems, and biodiversity effectively 
Figure 6 Average annual rate of forest cover loss (2010-2018).

23

Box 3: Preliminary findings from comparison of deforestation rates: need for more rigorous analysis

Finding 5: Recognizing the traditional and customary lands of IPs, LCs, and ADs will substantially contribute to, or even exceed, area-based conservation targets ....................................................25

Box 4: Recognizing land rights across Africa to achieve conservation targets...........................26

Figure 8: The area of IP and LC lands, both recognized and unrecognized, against the areas of formally protected areas and important conservation areas as a proportion of a country's

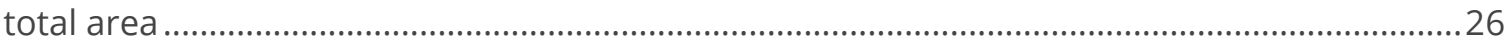

Table 5: The average cost of recognizing rights across five countries vs resettling under Scenario 1

Conclusion: Conservation goals can be achieved through community rights-based conservation 28

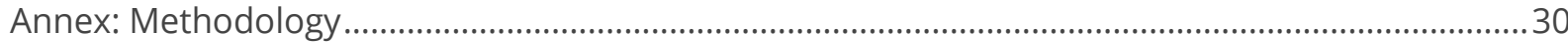

Mapping important biodiversity areas and priority conservation areas..........................................30

Integrating important biodiversity conservation areas and people ...............................................31

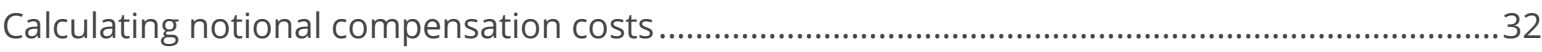

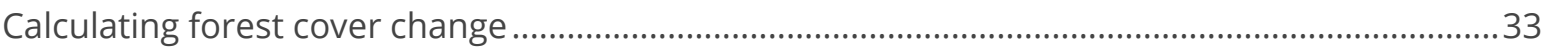

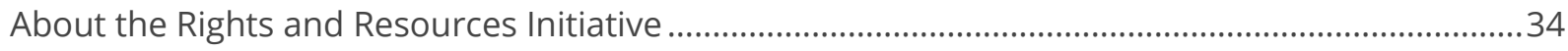

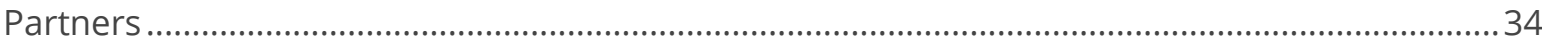

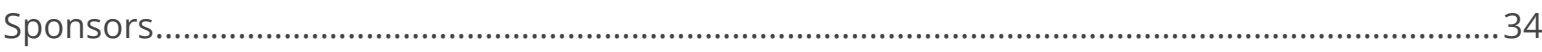

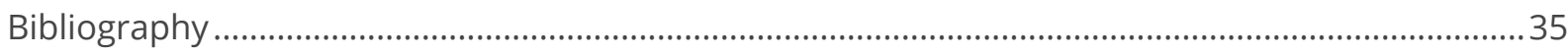




\section{Executive Summary}

Urgent action is needed to prevent the collapse of biodiversity across the planet. In an effort to propose solutions, certain governments, organizations and conservationists have put forward proposals for bringing 30 percent and up to 50 percent of the planet's terrestrial areas under formal "protection and conservation" regimes $^{[1,2]}$ to address the dual biodiversity and climate change crises. ${ }^{[3-7]}$ However, given that important biodiversity conservation areas often overlap with territories inhabited and claimed by Indigenous Peoples' (IPs), local communitiesii (LCS), and Afrodescendants ${ }^{\text {iii }}$ (ADs), expanding biodiversity conservation can impact these communities significantly. Indeed, conservation's colonial history has contributed to a growing list of human rights abuses, ${ }^{[8-11]}$ displacements, ${ }^{[12-18]}$ and increasingly militarized forms of violence ${ }^{[19-24]}$ in the pursuit of protecting biodiversity. It has been estimated that up to 136 million people were displaced in formally protecting half of the area currently protected (8.5 million $\left.\mathrm{km}^{2}\right) .{ }^{[16]}$

The current draft of the Convention on Biological Diversity post-2020 Global Biodiversity framework includes the goal of safeguarding at least 30 percent of the planetiv through protected areas and other effective conservation measures (OECMs). ${ }^{\vee}$ Thus far, however, it does not the guarantee that the rights of IPS, LCS, and ADs will be fully respected and promoted. If conservation actors, governments and IPS, LCS, and ADs work together, this new 10-year global framework could actively redress conservation's colonial history, and begin decolonizing ${ }^{[25]}$ conservation by substantively engaging with community led rights-based conservation approaches. With 190 countries negotiating the United Nations Post-2020 Global Biodiversity Framework, this is an important opportunity to codify a rights-based approach to conservation.

This report is informed by the imperative to prevent the collapse of biodiversity while respecting the tenure and human rights of IPs, LCs, and ADs. ${ }^{[26]}$ It seeks to highlight the risks and opportunities for IPs, LCs, and ADs arising out of the proposed expansion of conservation areas by asking the following questions:

1. How many people live within important biodiversity conservation areas (see table of key terms), including existing protected areas that could be affected by future conservation action required to meet biodiversity protection imperatives?

2. What is the distribution of people living in important biodiversity conservation areas according to income status of countries?vi

3. As a notional exercise, what could be the potential financial cost of exclusionary conservation practices applied to all high biodiversity value terrestrial areas?

4. What are the costs and benefits of community rights-based conservation as an alternate pathway for expansion of areas under conservation to meet biodiversity goals?

5. To what extent would recognizing and enforcing the collective tenure rights of IPs, LCS, and ADs contribute towards area-based targets for conservation?

The need for this analysis arose from the apprehensions facing many Indigenous and community organizations about the proposed area-based expansion of conservation, given its long history of 
dispossession and exclusion. It was also strengthened by the sincere efforts from some of the proponents of expanding conservation in a bid to support rights-based measures respecting the customary rights, knowledge, and practices of IPS and LCS. The report is further informed by RRI findings that IPS, LCs, and ADs lay claim to nearly half the world's terrestrial area, and that most of the planet's existing biodiversity exists in these lands and territories.

This data-driven report builds evidence for community rights-based conservation; and for the need to forge alliances between conservation actors and IPS, LCs, and ADs to prevent a biodiversity collapse. It ultimately seeks to inform policy processes at local, national, and global levels, including the CBD COP-15 scheduled in 2021, to provide arguments for an effective, just, and sustainable future for biodiversity conservation.

\section{Key Findings}

- Between 1.65 billion to 1.87 billion IPs, LCs, and ADs live in important biodiversity conservation areas, of which 363 million inhabit existing protected areas.

- Over half (56 percent) of the people living in important biodiversity conservation areas (including existing protected areas), are in low- and middle-income countries. The burden of conserving biodiversity falls disproportionately on the rural poor living in low- and middleincome countries, with people in high-income countries forming just 9 percent of the population of important biodiversity conservation areas.

- The large number of people living in important biodiversity conservation areas and the ethical mandate to pursue actions that promote equity, poverty eradication, and sustainable development preclude the use of strict conservation approaches associated with human rights violations, conflict, and high implementation and maintenance costs. With our conservative compensation calculation, we find that the financial cost for resettling as few as 1 percent of the people in a country's important biodiversity conservation areas supersedes the cost of recognizing all tenure rights in that jurisdiction.

- IPs, LCs, and ADs effectively conserve forests, ecosystems, and biodiversity through collective ownership, governance strategies, and traditional ecological knowledge. As a result, they present a viable alternative to exclusionary conservation practices. IPs, LCs, and ADs make investments equal to a quarter of global investment in conservation and manage and protect biodiversity efficiently at a lower cost and without the support received by conservation organizations, making rights recognition a just and effective alternative to exclusionary conservation practices.

- Equitable alliances between conservation actors and IPS, LCS, and ADs prevent deforestation and land use changes better than protected areas managed exclusively by public or private entities.

- IPS, LCs, and ADs are estimated to have grounded claims to over half of the planet's terrestrial area - however, their ownership rights are recognized on just 10 percent of the planet's terrestrial area. Addressing this gap and securing the customary land and territorial rights of IPS, LCS, and ADs should be a central component of any global strategy to protect 
or conserve at least 30 percent or 50 percent of the planet - and could even exceed these targets.

\section{Recommendations}

\section{For Intergovernmental Organizations and Institutions:}

- Promote the legal recognition and protection of the land and territorial rights of IPS, LCs, and $A D s$, including their right to self-determination and self-strengthening of their traditional knowledge and governance systems, as the basis for achieving the targets and priorities of the post-2020 global biodiversity framework.

- Advance the inclusion of legally enforceable safeguards in the Convention on Biological Diversity's Global Biodiversity Framework to both protect and extend the land and governance rights of IPs, LCS, and ADs and ensure their free, prior and informed consent in the creation of protected or conserved areas.

- Uphold existing rights standards and encourage parties to adopt the "Gold Standard" principles for best practice for recognizing and respecting Indigenous, Afro-descendant and community rights in the context of climate, conservation, and sustainable development actions (developed by the Global Landscapes Forum (GLF), the Indigenous Peoples Major Group (IPMG) for Sustainable Development, and RRI).

- Support IPs and local communities to have their own voices represented directly in the UN Biodiversity process with a seat at the table as full partners and conservation leaders.

- Establish independent grievance redress mechanisms-with the support of regional Indigenous federations, the UN Special Rapporteur on the Rights of Indigenous Peoples, the UN High Commissioner for Human Rights, the CBD Secretariat, and IUCN—to strengthen accountability of conservation efforts, redress infringements of human rights, and enforce compliance. ${ }^{[10]}$

- Increase funding for initiatives and projects that secure land tenure rights as an effective biodiversity conservation strategy

\section{For Conservation Organizations and Philanthropists:}

- Support efforts by IPs, LCs, ADs, and the youth and women within these groups to advance their land and livelihood rights in important biodiversity conservation areas.

- Prioritize actions and investments that advance the legal recognition and protection of tenure rights, the right to self-determination, and protection and valuation of traditional ecological knowledge held by IPs, LCs, and ADs.

- Endorse the "Gold Standard" principles for best practice for recognizing and respecting Indigenous, Afro-Descendant and community rights, and ensure its effective implementation through appropriate accountability mechanisms (i.e. organization specific criteria, indicators, trainings, transparent monitoring, and reporting). 
- Strengthen collaboration with IPs, LCS, and ADs and the pursuit of territories of life ${ }^{[27]}$ to facilitate inclusive conservation initiatives, ${ }^{[28]}$ while respecting their agency, self-determined priorities, and free, prior and informed consent in all externally funded initiatives.

- Support local governance institutions and decision-making platforms to support joint learning, resolve conflicts, redress grievances, and develop life plans as well as equitable benefit-sharing approaches.

- Support existing initiatives by IPs, LCs, and ADs in their struggles for rights as a central strategy for achieving inclusive and culturally appropriate community rights-based approaches.

- Support the flow of funding and capacity building resources to organizations representing IPs, LCs, and ADs to facilitate the recognition and securing of rights and governance of their lands and territories.

\section{For Governments:}

- Implement culturally appropriate legal, institutional, and regulatory reforms to recognize and protect the customary land and resource rights of IPS, LCS, ADs, and the women among them.

- Recognize the rights of IPS, LCS, ADs, and the women within these groups over existing protected areas, and in important biodiversity conservation areas. Work with organizations representing these groups to develop culturally appropriate frameworks for rights-based conservation regimes.

- Uphold the distinct and differentiated rights of IPS, LCS, and ADs, including their right to self-determination, locally adapted governance institutions, and culturally appropriate land use priorities.

- Commit national and ODA funds for nature protection and conservation towards supporting effective conservation efforts by IPs, LCs, and ADs.

- Ensure that Indigenous and community conservation efforts are counted in post 2020 global area-based targets. This will enable the integration of Indigenous land rights into national conservation plans and provide recognition for the conservation contributions of these groups.

- Establish and finance national accountability and reparation mechanisms to address past and present human rights violations in state-sanctioned protected areas as well as privately managed conservation areas. ${ }^{[8]}$

\section{Acknowledgements and Disclaimers}

This technical report is authored by Thomas Worsdell, Kundan Kumar (RRI), James R. Allan (University of Amsterdam), Gwili E. M. Gibbon (Durrell Institute of Conservation and Ecology), Andy White (RRI), Arvind Khare (RRI), and Alain Frechette (RRI).

The spatial data analysis for this report was carried out by James R. Allan, Scott C. Atkinson (UNDP), Gwili E. M. Gibbon, and Piyush Mehta (University of Delaware). 
Data layers contribution - James R. Allan and Gwili E. M. Gibbon.

Deforestation data contribution - Tin Garcia (TMP Systems).

People who commented and provided inputs:

Omaira Bolaños, Laura Valencia, Shannon Johnson, Bryson Ogden, Kendi Borona, Madiha Waris

Qureshi, Luke Allen, Tessa Ullmann, Anwesha Dutta, Ashwini Chhatre, Francis Masse, Alexander

Dunlap, Robert J. Smith, Janis B. Alcorn, Augusta Molnar, Joana Canelas, Teklehaymanot G.

Weldemichel, Elaine (Lan Yin) Hsiao, Simone Hoyte, William Sunderlin, Edmund Barrow, Karol

Boudreaux, Jane Carter, Antoine Kalinganire, and Gam Shimray.

Recommended citation: Rights and Resources Initiative. (2020). Rights-Based Conservation: The path to preserving Earth's biological and cultural diversity? Washington, DC: Rights and Resources Initiative.

Table of key terms/data sets

Key Term

Afro-

descendants

rights-based

conservation

\begin{tabular}{l} 
Exclusionary \\
conservation \\
\\
Existing \\
Protected \\
Areas \\
\hline $\begin{array}{l}\text { Important } \\
\text { biodiversity } \\
\text { conservation } \\
\text { areas }\end{array}$
\end{tabular}

areas
As per the Declaration of Santiago of 2000, the States of the Americas defined Afro-descendant as "the person of African origin who lives in the Americas and in the region of the African Diaspora as a result of slavery, who have been denied the exercise of their fundamental rights."vii In Latin America and the Caribbean, constitutional and legal recognition of Afro-descendants' collective tenure rights is based on their special cultural, ethnic, and spiritual relationship with land. Colombia, Brazil, Ecuador, Nicaragua, and Honduras, including others, have such legislation.

Community rights-based conservation refers to culturally appropriate conservation initiatives supported through the self-determination and collective agency of communities granted through the secure and inalienable collective tenure rights over their traditional lands. Community rights-based conservation strategies account for the historical context of rights recognition and dispossession in the country in which they are enacted, and actively counter existing frameworks that hinder rights recognition by implementing reforms through inclusive processes. In recognizing the inalienable tenure rights of "territories and areas conserved by indigenous peoples and local communities" (ICCA), or "territories of life," community rightsbased conservation integrates equitable and inclusive benefit sharing and decision-making through exercising the agency of communities and obtaining their full Free, Prior and Informed Consent (FPIC) for any initiative. [29]

Exclusionary conservation has been used to describe strictly managed protected areas which displace, restrict access, and limit the agency of a community to practice their traditional ways of life. These are often associated to IUCN categories la, lb, and II (Strict Nature Reserves, Wilderness Areas, and National Parks respectively) which can detrimentally impact communities if FPIC, communities' right to self-determination, and culturally appropriate strategies are not respected or applied.

Existing protected area data was taken from the World Database on Protected Areas (WDPA) which is the most comprehensive database on marine and terrestrial protected areas. It is updated monthly. It is a joint project between UN Environment and the International Union for Conservation of Nature (IUCN). The compilation and management of the WDPA is carried out by UN Environment World Conservation Monitoring Centre (UNEPWCMC). This is facilitated through collaborations with governments, non-governmental organizations, academia, and industry. The IUCN defines a protected areas as a "clearly defined geographical space, recognized, dedicated and managed, through legal or other effective means, to achieve the long-term conservation of nature with associated ecosystem services and cultural values". ${ }^{[30]}$

All scientifically determined areas in need of conservation attention to prevent the collapse of biodiversity and with it, maintaining the function of natural systems essential for life on earth. These areas include existing protected areas, KBAs, Wilderness areas, and the prioritization scenarios. Existing protected areas are also important biodiversity conservation areas and continue to require conservation attention as formal protection is not enough to guarantee continued conservation effectiveness. 
Indigenous Peoples

For RRI, the term "Indigenous Peoples" follows the definition or "statement of coverage" contained in the International Labor Organization Convention on Indigenous and Tribal Peoples in Independent Countries. Therefore, it includes:

i. peoples who identify themselves as "Indigenous";

ii. tribal peoples whose social, cultural, and economic conditions distinguish them from other sections of the national community, and whose status is regulated wholly or partially by their own customs or traditions or by special laws or regulations;

iii. traditional peoples not necessarily called Indigenous or tribal but who share the same characteristics of social, cultural, and economic conditions that distinguish them from other sections of the national community, whose status is regulated wholly or partially by their own customs or traditions, and whose livelihoods are closely connected to ecosystems and their goods and services. While RRI recognizes that all people should enjoy equal rights and respect regardless of identity, it is strategically important to distinguish Indigenous Peoples from other stakeholders. They have a distinct set of rights linked to their social, political, and economic situation as a result of their ancestry and stewardship of lands and resources vital to their wellbeing.

Key

Biodiversity

Areas (KBA)

LandScan

2018

Local

Communities

"Life"

prioritizations

(Scenarios)

Areas
KBAs are "sites contributing significantly to the global persistence of biodiversity" in terrestrial, freshwater, and marine ecosystems as identified by the World Database of Key Biodiversity Areas (managed by BirdLife International). This report has only used terrestrial KBAs due to their applicability to population distribution data.

Oak Ridge National Laboratory's LandScan is a standard for global human population distribution data. It represents an ambient population (average over 24 hours) distribution at approximately $1 \mathrm{~km}, 835$ meters ${ }^{2}$, $\left(30^{\prime \prime} \times 30^{\prime \prime}\right)$ spatial resolution.

Recognizing that local communities are not formally defined under international law, RRI considers that they encompass communities that do not self-identify as Indigenous but who share similar characteristics of social, cultural, and economic conditions that distinguish them from other sections of the national community, whose status is regulated wholly or partially by their own customs or traditions, who have long-standing, culturally constitutive relations to lands and resources, and whose rights are held collectively.

Indigenous Peoples, local communities, and Afro-descendants steward the lands and waters of their territories as a matter of survival, health and the collective wellbeing of all life coinhabiting areas. These "territories of life", abbreviated as ICCAs, embody the multitude of complex relationships, values, and beliefs that conseve biological and cultural diversity. ICCAs, formally entered international discourses through the IUCN World Conservation congress 2008 held in Barcelona and are "the heart of [IPs', LCs', and ADs'] identities, cultures, histories and livelihoods."[31]

Three prioritization scenarios would secure all important biodiversity conservation areas and a suitable portion of more than 28,000 terrestrial species ranges while a) minimizing the land area required (Scenario 1); b) minimizing overlap with human populations and infrastructure (human footprint) (Scenario 2); and c) minimizing overlap with agriculturally suitable lands (Scenario 3). Along with KBAs and wilderness areas, the scenarios would encompass the additional areas needing conservation attention to prevent the collapse of biodiversity.

Wilderness areas are defined as areas free of industrial scale activities and other human pressures which result in significant biophysical disturbance. ${ }^{[32-34]}$ They are important for biodiversity conservation and sustaining the key ecological processes underpinning planetary life-support systems, ${ }^{[32]}$ are extensively used in forming global policy, and hold linguistic, spiritual, and cultural value for Indigenous and local communities. ${ }^{\text {[33- }}$

36] While recognizing the harmful consequences of the $19^{\text {th }}$ century conceptualization of natural areas as "wild" and free of humans $1,[37,38],[13,39-41]$ this research accepts "wilderness" areas as having low human footprint (a human footprint value of $<1$ ), which does not exclude Indigenous Peoples and local communities. ${ }^{[32,42]}$ For RRI, and the growing scientific community, ${ }^{[32,42] ~ " w i l d e r n e s s ~ a r e a s " ~ a r e ~ h i s t o r i c a l l y ~ i n h a b i t e d ~ a n d ~}$ customarily managed by Indigenous Peoples and local communities to the extent that their human activities have shaped "wilderness areas" to what we see today. ${ }^{[43-46]}$ 


\section{Community rights-based conservation: Recognizing Indigenous Peoples, local communities, and Afro-descendants' rights to achieve conservation targets}

Over 1 million species are currently threatened with the risk of extinction ${ }^{[47]}$ in what is now widely regarded as the sixth major extinction event in Earth's history. ${ }^{[48]}$ In an effort to respond to the crisis, and build from the Aichi Biodiversity Targets, there have been calls to formally protect 30 percent to 50 percent of the planet's terrestrial areas. ${ }^{[49-51]}$ With 15 percent of the earth's terrestrial surface already under formal protection, within International Union for Conservation of Nature (IUCN) management categories, ${ }^{[52]}$ these calls could imply rapidly doubling or tripling the terrestrial areas under formal conservation regimes.

Both existing protected areas and proposed conservation areas are inhabited by large numbers of IPs, LCS, and ADs who are estimated to customarily manage at least 50 percent of the planet's terrestrial area. ${ }^{\left[53,{ }^{54]}\right.}$ Forty percent of existing protected areas ${ }^{[55]}$ and 36 percent of intact forest landscapes ${ }^{[56]}$ are estimated to overlap with Indigenous territories. When local communities' and Afro-descendants' claimed lands are included, these overlaps could be as high as 80 percent. ${ }^{[57]} \mathrm{A}$ common interest exists between IPs, LCs, and ADs claiming customary ownership and governance rights over their traditional lands and conservation actors attempting to conserve the biodiversity held within these territories of life. However, if historical patterns of protected area formation are followed for proposed expansion, IPs, LCs, and ADs who inhabit high-conservation-value landscapes will be deeply affected by centrally applied conservation efforts that displace, exclude, or limit access to land and natural resources.

This report addresses the potential risks IPs, LCs, and ADs face when conservation efforts are expanded to cover 30 percent or 50 percent of Earth's terrestrial areas. viii It builds on the findings of the "Cornered by Protected Areas" series, and associated releases, which documented and compiled case studies on human rights abuses committed in the name of protecting biodiversity across 27 countries. ${ }^{[8,10,58,59]}$ Efforts to prevent biodiversity collapse also provide opportunities, through rights-based conservation, for equitable, effective, and just solutions to social and environmental issues. The report seeks to highlight these opportunities by drawing from a growing body of literature which support community-led conservation practices and collective tenure regimes to achieve biodiversity targets. ${ }^{[8,10,26,47,60,61]}$

The analysis is also informed by the fact that many in the global conservation and climate change mitigation community, including intergovernmental platforms, are starting to consider alternative rights-based strategies to address the global climate, biodiversity, and land degradation crises. ${ }^{[47,61]}$ For example, the United Nations' Decade on Ecosystem Restoration has embedded rights-based restoration at the core of its strategic framework. ${ }^{[62]}$ The Intergovernmental Panel on Climate Change's (IPCC) 2019 report also recognized the importance of securing IPs', LCs', and women's land rights for fighting climate change. ${ }^{[61]}$ The IPCC report also acknowledged the need to create effective policies that enable land titling, and enable the empowering of communities that land titling entails. ${ }^{[61]}$ Some of the proponents of area-based solutions to conservation strongly endorse community-led rights-based conservation as the pathway for achieving global biodiversity targets. 
However, the momentum behind community rights-based conservation is jeopardized by the absence of political will to advance environmental targets and by pervasive tenure insecurity globally. ${ }^{[53,54]}$ In this context, global frameworks for conservation that do not guarantee the rights of IPs, LCs, and ADs risk undermining the next decade of conservation and climate change mitigation strategies. These limitations are highlighted in the recent release of the fifth Global Biodiversity Outlook by the Secretariat of the CBD which found that all Aichi Biodiversity Targets were missed by governments and only six of these were partially completed. ${ }^{[63]}$

The report is divided into five findings and a conclusion. Each finding contains a brief description of the methodology under the figure or table. For the full methodology please refer to the Annex at the end of the report.

\section{Finding 1: The population of IPs, LCs, and ADs living in important biodiversity conservation areas ranges between 1.65 billion to 1.87 billion people}

The RRI analysis used three scenarios ${ }^{[7]}$ which identify important areas for biodiversity conservation-including existing protected areas-that require conservation management, and calculated the human population inhabiting these areas. The three spatial projections, developed by Allan et al., ${ }^{[7]}$ combined areas of conservation importance (key biodiversity areas, ${ }^{[64]}$ protected areas, $^{[65]}$ and wilderness areas ${ }^{[32]}$ ) with prioritizations that cover a suitable portion of more than 28,000 terrestrial species ranges. These projections therefore identify additional unprotected areas that require additional conservation attention. The three prioritization scenarios secured important conservation areas and terrestrial species ranges while a) minimizing the land area required (Scenario 1) (Figure 1); b) minimizing overlap with human populations and infrastructure (human footprint) (Scenario 2); and c) minimizing overlap with agriculturally suitable lands (Scenario 3). These combined areas form part of the most comprehensive estimate of the minimum land area requiring conservation attention to prevent the collapse of biodiversity ${ }^{[7]}$ and were used to estimate the number of IPs, LCs, and ADs living within them. These layers are not being used to promote any particular spatial conservation strategy, but to highlight the magnitude of populations who live in areas identified as important for the conservation of species and their habitats. (For detailed methodology, refer to the Annex.)

All terrestrial area percentages exclude Antarctica. The spatial data of existing protected areas was obtained from a 2017 version of the World Database on Protected Areas (WDPA), which still contains important data on protected areas in China. ${ }^{[65]}$

This report has not analyzed marine protected areas as population distribution data is incapable of addressing issues of the use, access, and management of water bodies and their resources. Though water rights, and issues of access to water related resources, are relevant in the conservation debate, analyzing and addressing these issues is beyond the scope of this analysis and will require further research. 
Figure 1: Human populations living within the "minimum land area" required to conserve terrestrial biodiversity

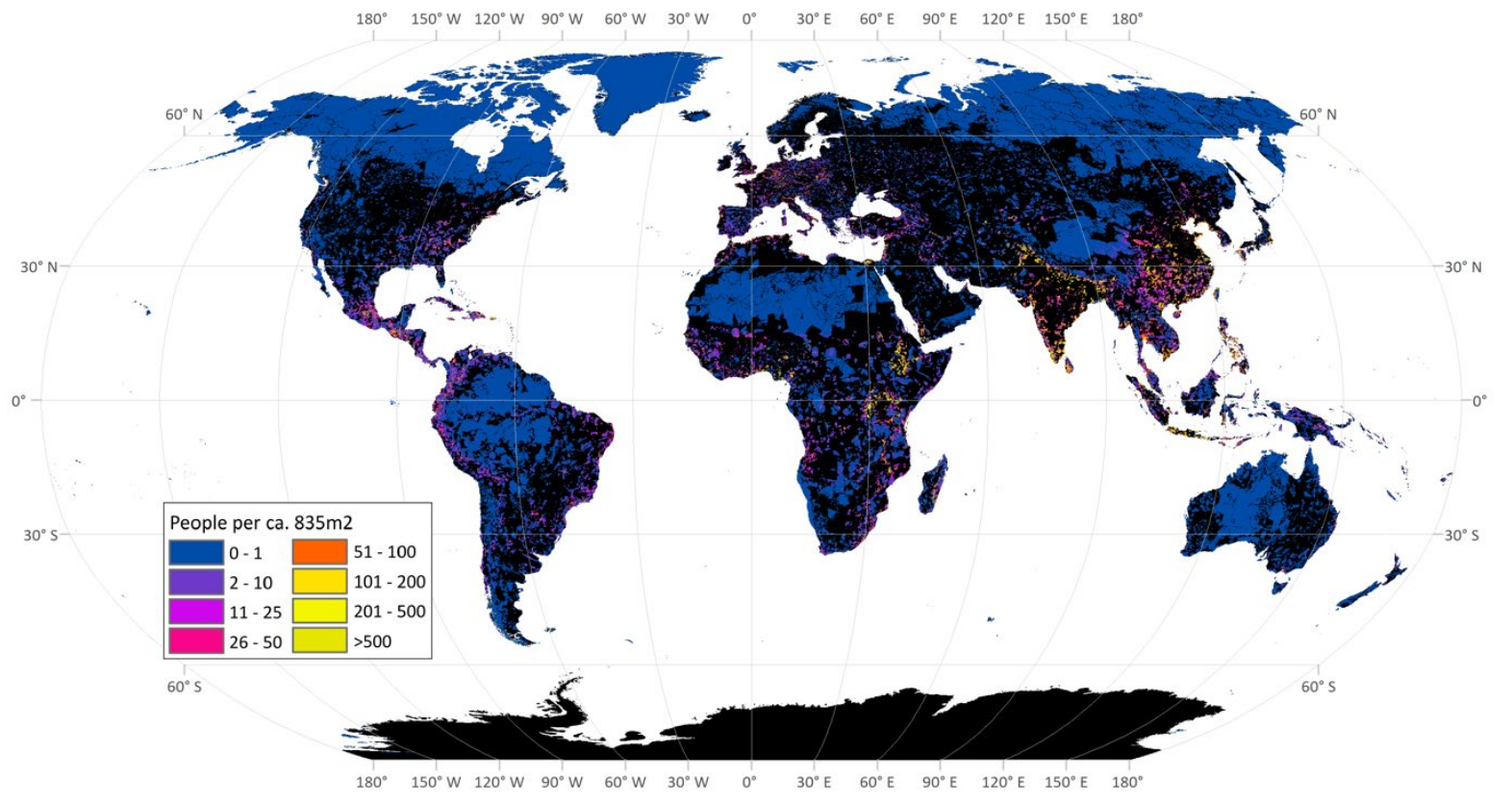

The populations living within the "minimum land area" were estimated using the LandScan 2018 ${ }^{[66]}$ global population distribution. The "minimum land area" required to conserve terrestrial biodiversity was calculated by Allan et al. ${ }^{[7]}$ This map (Figure 1) includes existing protected areas (15 percent) (represented in green within Figure 2), non-protected Wilderness (20 percent) and Key Biodiversity Areas ( 4 percent) and new conservation priority areas to ensure the minimum area for species persistence ${ }^{[7]}$ under Scenario 1. Together, these areas encompass 47 percent of the Earth's terrestrial area (excluding Antarctica) and are home to 1.87 billion people (Table 2). Blue represents low populations and the progression towards purple, red and yellow emphasize the increase in human population within important biodiversity conservation areas. [Annex]. 
Figure 2: Human populations living within the "minimum land area" required to conserve terrestrial biodiversity, highlighting existing protected areas

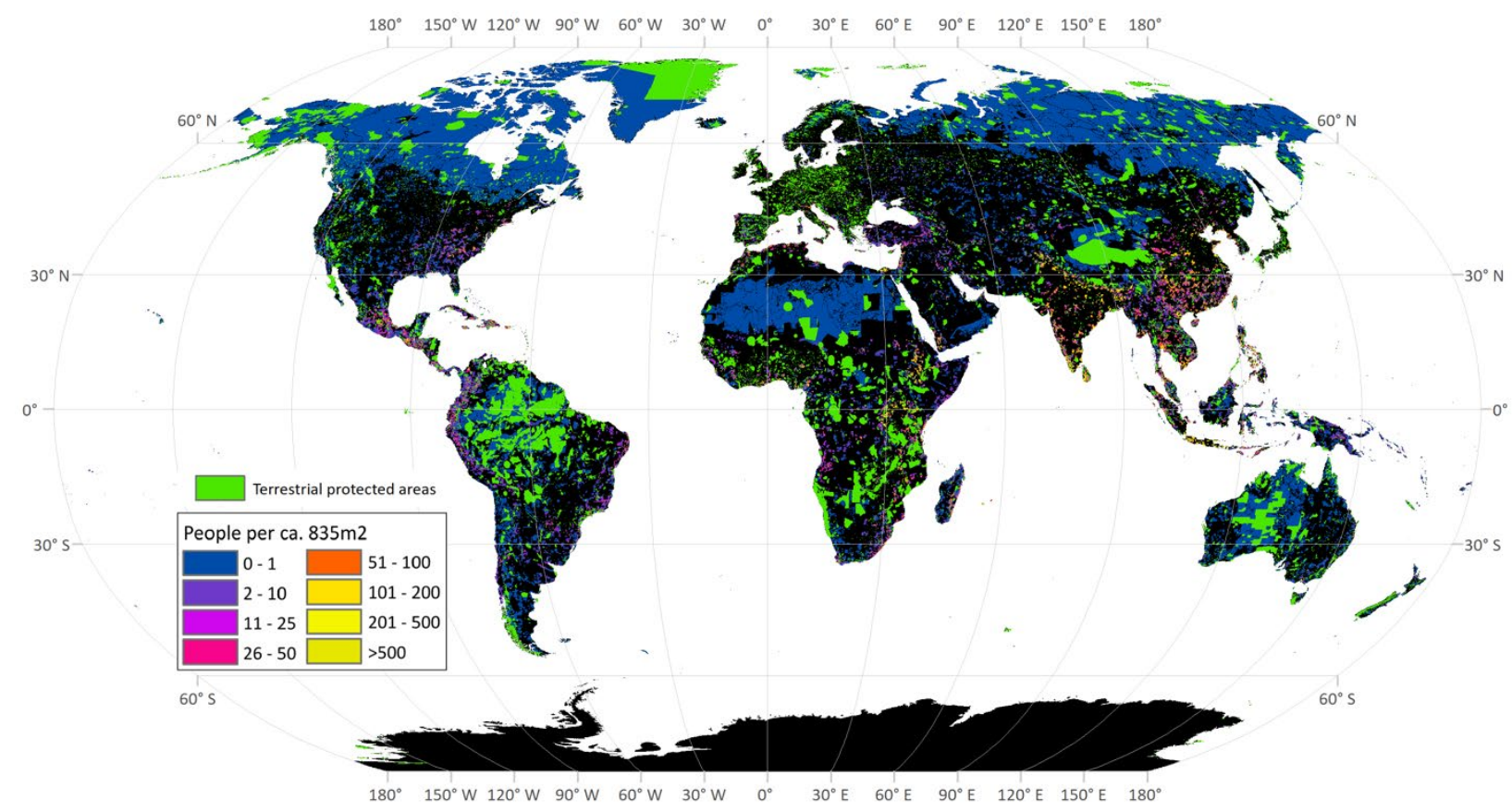

Table 1: People living across important biodiversity conservation areas

\begin{tabular}{|c|c|c|}
\hline $\begin{array}{l}\text { Important Biodiversity } \\
\text { Conservation Areas }\end{array}$ & $\begin{array}{l}\text { Percentage Terrestrial Cover } \\
\text { Excluding Antarctica } \\
\text { (million } \mathbf{k m}^{2} \text { ) }\end{array}$ & $\begin{array}{l}\text { People living in Important Biodiversity } \\
\text { Conservation Areas (Millions) }\end{array}$ \\
\hline Existing Protected Areas & $15 \%(20.3)$ & 362.8 \\
\hline Key Biodiversity Areas & $9 \%(11.5)$ & 309.8 \\
\hline Wilderness Areas & $26 \%(35.1)$ & 2.6 \\
\hline $\begin{array}{l}\text { Additional (Scenario 1): Minimizing } \\
\text { the land area required }\end{array}$ & $9 \%(11.7)$ & 1262.1 \\
\hline $\begin{array}{l}\text { Additional (Scenario 2): Minimizing } \\
\text { overlap with human populations } \\
\text { and infrastructure (human } \\
\text { footprint) }\end{array}$ & $9 \%(12.6)$ & 1037.6 \\
\hline $\begin{array}{l}\text { Additional (Scenario } 3 \text { ): Minimizing } \\
\text { overlap with agriculturally suitable } \\
\text { lands }\end{array}$ & $12 \%(16.2)$ & 1152.6 \\
\hline
\end{tabular}

Millions of people live in important biodiversity conservation areas (Table 1). Protected Areas, KBAs, wilderness areas, and the additional scenarios all cover important tracts of habitats and species ranges needing conservation attention, which when combined lead to the full scenarios 1,2 , and 3. ${ }^{[7]}$ (Table 2). Table 1 depicts the full extent of important biodiversity conservation areas, however, it is important to note that a significant portion of protected areas, KBAs, and wilderness areas overlap. ${ }^{[7]}$ These overlaps have been accounted for in combining the scenarios (Table 2). Between 1.65 to 1.87 billion people live in important biodiversity conservation areas (Table 2). [Annex]. 
Table 2: Combining important biodiversity conservation areas to achieve spatial targets

\begin{tabular}{l|c|c}
\hline $\begin{array}{l}\text { Important Biodiversity Conservation } \\
\text { Areas }\end{array}$ & $\begin{array}{c}\text { Percentage Terrestrial Cover of } \\
\text { important biodiversity conservation } \\
\text { areas Excluding Antarctica } \\
\text { (million km }{ }^{2} \text { ) }\end{array}$ & $\begin{array}{c}\text { People living in expansion } \\
\text { areas for conservation } \\
\text { (Millions) }\end{array}$ \\
\hline $\begin{array}{l}\text { (Scenario 1): Minimizing the land area } \\
\text { required } \\
\text { (Scenario 2): Minimizing overlap with } \\
\text { human populations and infrastructure }\end{array}$ & $47 \%(63.8)$ & 1871.9 \\
\hline $\begin{array}{l}\text { (Scenario 3): Minimizing overlap with } \\
\text { agriculturally suitable lands }\end{array}$ & $48 \%(64.6)$ & 1647.4 \\
\hline
\end{tabular}

Not all countries contribute equally in terms of the proportional national land area needed to ensure species persistence. ${ }^{[7]}$ This is also true with the proportional populations living within important biodiversity conservation areas, with some countries having a substantially larger percentage of people living in biodiverse areas (see Figure 3). Island nations, with their high concentration of endemic species, have a particularly high proportion of population living in important biodiversity conservation areas while Australia, Canada, the United States, and most of Europe do not (Figure 3). The majority of Asia, Africa, Oceania, the Caribbean, and North and Latin America have over 25 percent of their populations living within important biodiversity conservation areas. In Venezuela, for example, 49.9 percent of the population live in existing protected areas. For Europe, populations living in important biodiversity conservation areas are predominantly found in existing protected areas with only Montenegro and Iceland having substantial populations living in areas that need conservation attention. 
Figure 3: The proportion of a country's human population living within the "minimum land area" required to conserve terrestrial biodiversity

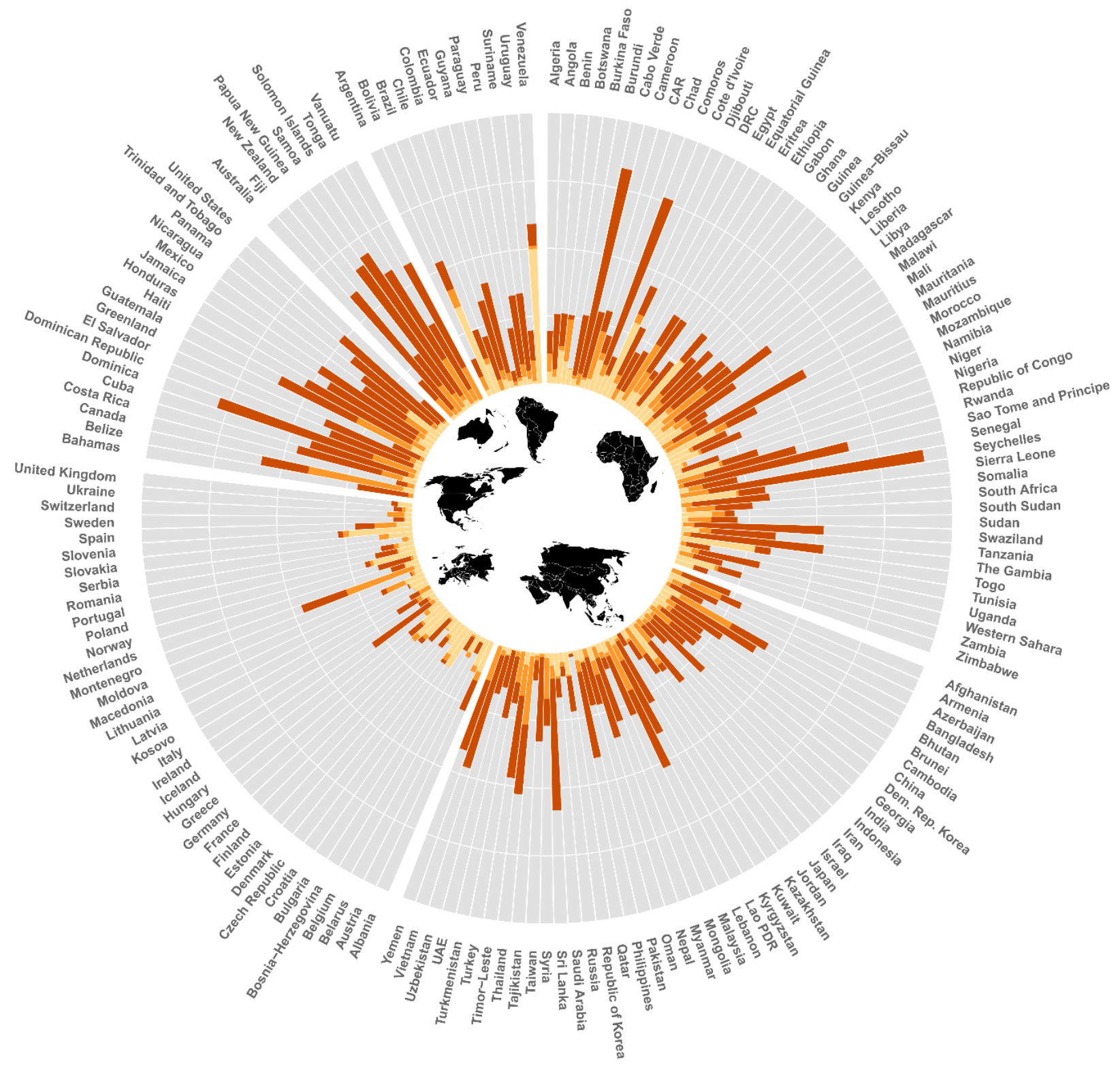

Using scenario 1, Figure 3 shows the proportion of a country's population living across different important biodiversity conservation areas. Moving from the center the bars represent the percentage of a country's population in existing protected areas (light orange), KBAs and wilderness areas (medium orange), the additional prioritization (scenario 1) for minimizing the land area required (dark orange), and populations not living in important biodiversity conservation areas (grey). The white rings divide the clock graph into four equal parts, each representing 25 percent of a country's population. [Annex]. 
Finding 2: A greater proportion of people living in important biodiversity conservation areas are in low and middle-income countries and may be placed at risk if exclusionary practices are used to expand conservation

To better understand who could be impacted by the urgent need to scale-up biodiversity conservation efforts, people living in important biodiversity conservation areas in different scenario areas were disaggregated according to a country's income status. ${ }^{[67]}$ Across the scenarios, highincome countries accounted for only 9 percent of the people living in important biodiversity conservation areas, whereas low- and lower-middle income countries accounted for 56 percent (see Figure 4). For scenarios 1, 2, and 3, China contributes 46 percent, 41 percent, and 42 percent of the people living in important biodiversity conservation areas in upper-middle income countries respectively.

Figure 4: Distribution of people living within important conservation areas by income status

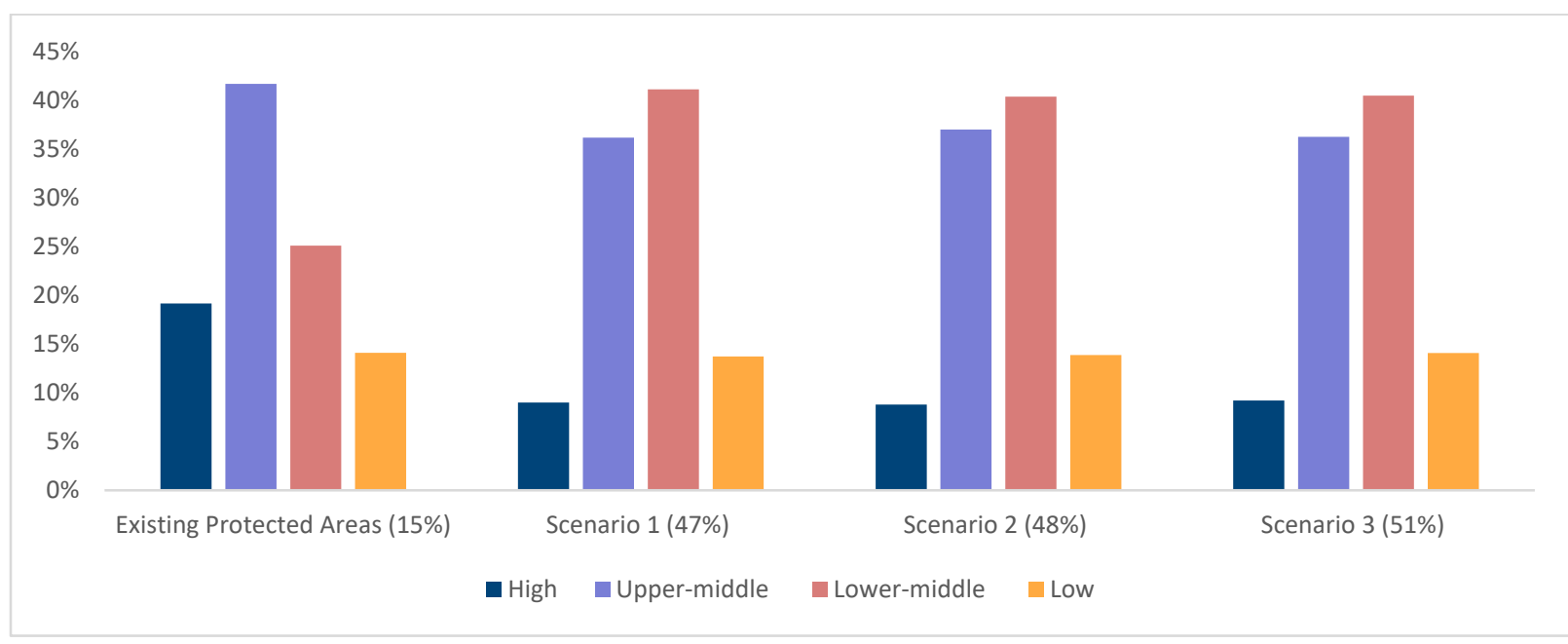

This analysis also examines population densities within important biodiversity conservation areas across income status (Table 3). The results reveal that the population densities of people living in important biodiversity conservation areas is much higher in low- and lower-middle income countries than in high- or upper-middle income countries (see Table 3). These density calculations do not include the people living within existing protected areas.

Table 3: Population density of important biodiversity conservation areas across respective income statuses

\begin{tabular}{l|c|c|c}
\hline Income Status & $\begin{array}{c}\text { Scenario 1 } \\
\text { (Covering 32.2\%) }\end{array}$ & $\begin{array}{c}\text { Scenario 2 } \\
\text { (Covering 32.8\%) }\end{array}$ & $\begin{array}{c}\text { Scenario 3 } \\
\text { (Covering 35.5\%) }\end{array}$ \\
\hline High & 7 & 5 & 6 \\
\hline Upper-middle & 26 & 23 & 22 \\
\hline Lower-middle & 126 & 103 & 97 \\
Low & 57 & 48 & 50 \\
\hline
\end{tabular}


The results in Table 3 reinforce the prior finding (Figure 4) that a disproportionate number of people living in important biodiversity conservation areas are in low- and lower-middle income countries. A significant portion of communities in low- and middle-income countries are more likely to depend on the natural resources held within their socio-ecological systems. Any exclusion from forested areas could therefore have profound impacts on food and livelihood security. ${ }^{[68]}$ These density calculations do not include the people within existing protected areas or an accurate estimate of nomadic/mobile populations.

Currently, 52 percent of existing protected areas are under IUCN management categories Ia, Ib, and II. ${ }^{i x}$ This means that strict nature reserves and national parks ${ }^{[30]}$ make up most of the protected areas in the world. The displacements, ${ }^{[13]}$ human rights abuses, ${ }^{[11,58,69]}$ and conflicts ${ }^{[19]}$ caused due to exclusionary conservation are well documented and strong evidence exists of negative impacts of restrictive and exclusionary conservation on communities ${ }^{[11,70-72]}$ who depend on natural resources for a large part of their livelihoods, ${ }^{[73]}$ subsistence, ${ }^{[74]}$ and wellbeing. ${ }^{[75]}$ Whether countries will continue this historical trajectory of favoring exclusionary protected areas for biodiversity conservation will determine the impact of conservation on the communities who inhabit important biodiversity conservation areas.

Figure 5: People vs Area as a proportion of country within scenario 1; the minimum land area for conserving biodiversity

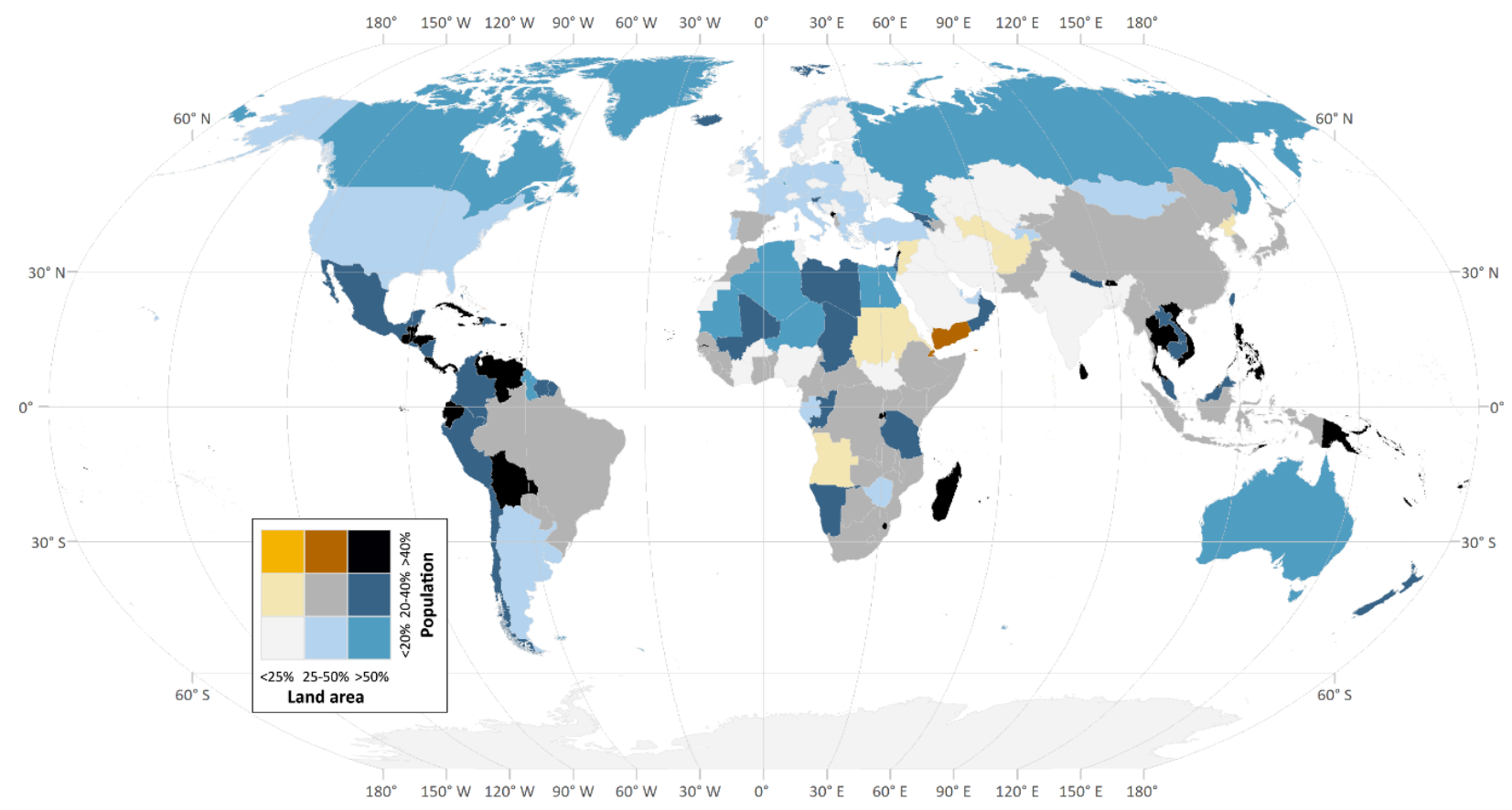

This bivariate map (showing two variables simultaneously) shows the proportional population and area by country that would be impacted if strict protected areas (particularly categories la, Ib, II) were to be expanded. Specifically, it highlights the percentage of an administrative area within the minimum land area required to conserve terrestrial biodiversity (Scenario 1), which includes existing protected areas, and the people living within these areas as a percentage of the country's 
total population. This map represents 47 percent of the Earth's terrestrial area needing conservation attention. Darker countries have a greater proportional area and population in important biodiversity conservation areas. [Annex].

The implications of the above analysis for the expansion of areas under conservation are significant. Positive conservation outcomes are linked to the ability of conservation initiatives to provide positive socio-economic benefits to communities through equitable benefit sharing and inclusive governance regimes. ${ }^{[76-78]}$ However, there is a considerable overlap between important biodiversity conservation areas and populations whose rights have yet to be recognized, in countries with poor protection of tenure rights. ${ }^{[54,79]}$ Excluding or restricting communities from lands prioritized for strict biodiversity conservation could have severe socio-economic impacts ${ }^{[18]}$ with disproportionate effects on rural women. ${ }^{[74,80,81]}$ The repercussions of restricting or excluding rural communities from priority conservation areas will be varied and many, leading to social, economic, and household stresses that will further exacerbate existing difficulties and challenges. ${ }^{[82,83]}$ Any restrictions on a community's access to natural resources is recognized as a form of displacement. ${ }^{[18]}$ Many in the conservation community recognize the importance of OECMs or rights-based alternatives as integral to the successful future conservation of species and habitats, ${ }^{[84]}$ and acknowledge that efforts to conserve biodiversity will likely overlap with areas under informal and customary governance systems which could be impacted through the centralization of decision-making and control. ${ }^{[85,86]}$ This extends to all marine areas, where secure and clearly defined community-based water tenure regimes are also essential for IPs', LCs', and ADs' livelihoods and food security, as well as to a country's efforts to achieve sustainable development priorities and ensure climate resilience. ${ }^{[87]}$

\section{Box 1: Non-timber forest products in India are essential to the economy and wellbeing of millions of people}

In India, over a fifth of the population - an estimated 275 million rural poor including 89 million tribal people - depend on Non-Timber Forest Products (NTFPs) for a substantial portion of their daily household income. ${ }^{[88]}$ NTFPs also contribute the equivalent of US $\$ 2.6$ billion per annum in revenues and absorb 50 percent of the employment in India's forestry sector. ${ }^{[88]}$ Where the rights of communities over forests and natural resources have been recognized and applied under the 2006 Forest Rights Act (FRA), the effective conservation and sustainable management of NTFPs has been realized. ${ }^{[89]}$ However, as of 2017, only 3 percent of the potential FRA area has been recognized. ${ }^{[89]}$ Our analysis shows that 272 million people inhabit important biodiversity conservation areas in India (Scenario 1). Considering the importance of NTFPs for food security, ${ }^{[74]}$ economic empowerment, ${ }^{[73]}$ enhancing the wellbeing of vulnerable tribal populations, ${ }^{[75]}$ and poverty alleviation, ${ }^{[90,91]}$ conservation initiatives must ensure restrictions do not detrimentally impact the lives of these communities and should in fact enhance the wellbeing of local people. The Indian government has not accepted that its "strongest conservation provisions"[92] are in a law created for recognition of community rights over forests, and consequently, the environment ministry has not realized the full potential of implementing the FRA as a strategy for protecting critical wildlife habitats. ${ }^{[92]}$ 
Finding 3: Expanding conservation areas by using historically dominant models of exclusionary conservation would be highly contentious, prohibitively expensive and come with human rights costs that will fuel land conflicts

Displacement for conservation is a highly contentious issue that has long divided the conservation community. ${ }^{[93]}$ Allegations of persistent evictions are common against conservation actors, ${ }^{[8,10,59,94,}$ 95] supporting the narrative that protected areas have been built on "histories of exclusion". ${ }^{72]}$ Human rights abuse, dispossession, and the displacement of IPS, LCS, and ADs due to exclusionary conservation practices are well-documented phenomena and a rapidly growing area of study. ${ }^{[13,14,}$ $16,39,96-98$ ] While the full extent of human rights abuses and displacement is unknown, research has estimated that up to 136 million people may have been displaced in formally protecting less than half of the area currently under formal protected status (8.5 million $\left.\mathrm{km}^{2}\right){ }^{[16]}$

There have been efforts to address conservation-linked displacement, or involuntary resettlement ${ }^{\mathrm{x}}$ (where the "right of way" overpowers the "right to stay" of inhabiting communities), ${ }^{[97]}$ by creating provisions under national laws for voluntary forms of resettlement. However, these provisions are often drafted and promulgated through collaborations with conservation organizations, consequently favoring their interests over those of people and communities sharing biodiverse spaces with wildlife. ${ }^{[99]}$ There are also reports of "voluntary" relocation practices being carried out through coercion and force. ${ }^{[72]}$ Compensation for resettlement and lost livelihoods, another suggested potential strategy for mitigating the negative impacts of conservation projects on rural communities, ${ }^{[100]}$ also has a high potential for abuse.

Applying existing legislative frameworks, though legal, often still leads to human rights abuses. A study which analyzed the "compensation security" of 30 countries in Asia and Africa demonstrated that the majority of national frameworks fail to ensure the fair compensation of expropriated lands. ${ }^{[101]}$ The scope of applying resettlement-linked compensation for conservation is strongly critiqued by social scientists and civil society, regardless of whether resettlement is voluntary or involuntary, particularly in countries where democratic and governance processes are weak. ${ }^{[72]}$ Any form of involuntary relocation for conservation ignores the fundamental right of Indigenous Peoples and communities to free, prior and informed consent (FPIC). Given the substantial number of people living in important biodiversity conservation areas, any wide-scale application of strict conservation measures, which could lead to displacements and restrictions on access to resources, would impose costs on populations inhabiting these lands. One way of notionally estimating such risks is to assess the financial feasibility of relocating the populations that would be affected by an expansion of strict conservation areas. 


\section{Box 2: RRI Disclaimer on Notional Rehabilitation costs}

Rehabilitation practices, even when voluntary, have been rife with abuse and violation of rights. RRI strongly opposes displacement of IPS, LCs, and ADs for conservation. RRI has used the notional compensation cost only as a thought exercise to convey to the conservation community the huge costs in trying to expand protected areas using resettlement "best practices" and exclusionary conservation. These compensation estimates should not be a reference cost to minimize the negative socio-economic impacts linked to injustice, dehumanization, and displacement associated with conservation practices. RRI strongly discourages the use of this thought exercise for actual policy applications, apart from making the point that exclusionary conservation has extremely high financial cost for governments and conservation actors, and a more profound cost for communities living in the conservation areas which threatens their way of life.

Using cost figures from resettlement action plans (RAPs) produced by the International Finance Corporation (IFC), Asian Development Bank, and African Development Bank Group, ${ }^{\text {[102-105] }}$ relocation cost estimates for 1.2 - 1.5 billion people living in unprotected important biodiversity conservation areas range between US $\$ 4.0$ to US\$5.0 trillion (Table 4). While considerable, this notional cost remains an underestimate as it only uses the direct cost of physically resettling people. Absent from the cost estimate are the indirect costs of social, political, and cultural disruption; lost access to local, ecological, and cultural resources; non-monetizable assets (i.e. traditional ecological knowledge, historical roots, sacred sites, spiritual connections); and the multigenerational trauma of evicting communities whose identities are inextricably linked to their traditional lands and territories. This report has, by design, undervalued the compensation value attached to households as assigning a monetary "value would be completely inappropriate"[100] to traditional ecological knowledge systems, sacred sites, spiritual connections and cultures that are intrinsically linked to their socio-ecological territories. [Annex].

\section{Table 4: The notional cost of compensating people living within conservation priority areas}

\begin{tabular}{|c|c|c|c|c|}
\hline $\begin{array}{l}\text { Important Biodiversity } \\
\text { Conservation Areas }\end{array}$ & $\begin{array}{l}\text { Percentage Terrestrial } \\
\text { Cover } \\
\text { (Excluding Antarctica) }\end{array}$ & $\begin{array}{l}\text { People } \\
\text { (Millions) }\end{array}$ & $\begin{array}{l}\text { Area in million km2 } \\
\text { (without Antarctica) }\end{array}$ & $\begin{array}{l}\text { Compensation in } \\
\text { USD (Billions) }\end{array}$ \\
\hline $\begin{array}{l}\text { Existing formally Protected } \\
\text { Areas (WDPA) }\end{array}$ & $15.04 \%$ & 362.8 & 20.3 & - \\
\hline $\begin{array}{l}\text { Minimizing the land area } \\
\text { required (Scenario 1), expansion } \\
\text { areas }\end{array}$ & $32.23 \%$ & 1509.1 & 43.5 & 5141.9 \\
\hline $\begin{array}{l}\text { Minimizing overlap with human } \\
\text { populations and infrastructure } \\
\text { (human footprint) (Scenario 2), } \\
\text { expansion areas }\end{array}$ & $32.84 \%$ & 1284.6 & 44.3 & 4376.8 \\
\hline $\begin{array}{l}\text { Minimizing overlap with } \\
\text { agriculturally suitable lands } \\
\text { (Scenario 3), expansion areas }\end{array}$ & $35.54 \%$ & 1399.7 & 47.9 & 4769.0 \\
\hline
\end{tabular}

The findings show that efforts to displace and resettle even a small fraction of people living in important biodiversity conservation areas will be not only unjust but financially infeasible. Scaled up financial flows to meet biodiversity targets, in countries with poor governance and human rights records, will further incentivize powerful actors, including governments and the private sector, to 
continue displacing people whose customary rights remain unrecognized. Such processes are already being observed in Cameroon, ${ }^{[9]}$ Tanzania, ${ }^{[24,}{ }^{106]}$ South Africa, ${ }^{[22,}{ }^{107]}$ Kenya, ${ }^{108]}$ the Republic

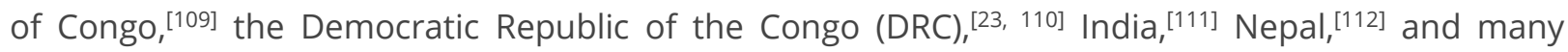
others, putting hundreds of millions of IPs, LCs, and ADs at risk.

Given that conservation areas generate their own economic benefits (through payment for ecosystem services, tourism, and grants/subsidies), ${ }^{[100]}$ the financialization of conservation could pose incentives for elite capture, ${ }^{[113]}$ especially in the absence of culturally appropriate legal safeguards and clear collective rights structures. ${ }^{[114]}$ Market-based environmental strategies have the potential to alter social dynamics through dominant top-down procedures which restructure land and a community's relationships with land. ${ }^{[15]}$ This risk is further exacerbated when governments and conservation donors appropriate the discourse of environmental crises to gain control over lands and resources ${ }^{[116]}$ which put environmental commitments at risk. ${ }^{[117]}$ In addition to directly affecting the customary rights of IPs, LCs, and ADs over territories that overlap with important biodiversity conservation areas, ${ }^{[55,56]}$ investments that restrict the right of communities to access, use, manage, and benefit from the lands and resources they depend on will ultimately result in social, economic, and environmental impacts. ${ }^{[118]}$ As IPS, LCS, and ADs have conserved and managed their customary lands for generations, through complex relationships and interdependencies with their environments, activities that prohibit communities from enacting traditional practices will interfere and subsequently undermine traditional practices and the biodiversity they support. For example, prohibiting traditional practices such as hunting, often a primary source of protein for communities, ${ }^{[119]}$ may not only impact food insecurity and poverty but also undermine conservation initiatives altogether. ${ }^{[120,121]}$

When socio-economic stresses mount, conflicts between local communities and conservation actors could lead to an increase in the militarization of conservation to protect financial interests in biodiversity assets. ${ }^{[19,20,122]}$ IPS, LCS, and ADs are important stakeholders in the conservation as their lands intersect with important ecological areas ${ }^{[55,123,124]}$ and play a central role in protecting important tracts of biodiversity ${ }^{[125]}$ as well as intact landscapes. ${ }^{[56]}$ The importance of traditional and customary approaches to nature conservation, as practiced by IPS, LCS, and ADs in various forms (e.g., "territories and areas conserved by indigenous peoples and local communities" or "territories of life," indigenous protected areas, and OECMs) have gained widespread traction and recognition in the CBD. ${ }^{[126]}$ Though IPs, LCS, and ADs customarily manage at least 50 percent of the planet's terrestrial area, they legally own just 10 percent, ${ }^{[53]}$ a result of historical processes of dispossession and non-recognition of their claims by modern nation states. Within a context of pervasive insecure tenure and resource rights, the rapid expansion of formal conservation areas to incorporate up to 50 percent of Earth's terrestrial area risks replicating and amplifying historical injustices- such as displacement through forced evictions, ${ }^{[14,24,58,59,110,127]}$ state-sanctioned physical violence, ${ }^{[24,58,59,}$ ${ }^{110]}$ the assimilation of cultures, and the loss of traditional ecological knowledge or systems ${ }^{[128,129]}$ should such a strategy fail to incorporate and promote community rights-based conservation within global conservation agendas. 
Finding 4: IPs, LCs, and ADs conserve forests, ecosystems, and biodiversity effectively

The lands and forests managed and governed by IPS, LCS, and ADs are able to suppress fires ${ }^{[130]}$ and resist forest loss, ${ }^{[131,132]}$ and consequently experience lower rates of deforestation. ${ }^{[130,133-139]}$ Their lands have enhanced carbon storage capabilities, ${ }^{[139-141]}$ contain important populations of threatened terrestrial vertebrate species, ${ }^{[125,139-142]}$ and protect biodiversity in general[47, 60, 61, 143] as well as or better than publicly-owned protected areas. Secure tenure rights contribute towards the effective stewardship of forests and territories. ${ }^{[114,135]}$ While up to 1.87 billion people live in important biodiversity conservation areas, 70 percent of these lands are still relatively intact. ${ }^{[7]}$

Across much of the world, and through precarious tenure security, IPs, LCs, and ADs are actively involved in conserving their ancestral and traditional lands and territories, making both direct and in-kind investments in the management, restoration, and preservation of the natural resource systems that they and others depend on. ${ }^{[58]}$ Recent estimates suggest that IPs, LCs, and ADs are collectively investing as much as US $\$ 3.16$ billion to US\$4.57 billion-equivalent to 15 to 23 percent of combined worldwide conservation spending of governments, donors, foundations, and NGOsin conserving their territories. ${ }^{[58,59]}$ In turn, support to their existing initiatives can cost less to establish, ${ }^{[144]}$ support, and maintain than conventional centrally managed protected areas. ${ }^{[145]}$ Given that the vast majority of conservation investments occur in high income countries, and select high-profile parks in a limited number of countries, evidence suggests that in low- and lowermiddle- income countries, contributions by IPS, LCs, and ADs likely constitute the majority of total countrywide conservation spending. ${ }^{x i}$ Data collected from 29 case studies in 14 countries found that IPS, LCS, and ADs invest an average of US\$3.57 per hectare on conservation practices in their territories. ${ }^{[58]}$ As a comparison, the total expenditure on protected areas in low- and middle-income countries (excluding contributions by communities) was found to be US\$0.62/ha in Brazil, US\$4.00/ha in India, US\$9.21/ha in Indonesia, US\$10.78/ha in Kenya, and US\$3.78/ha in Peru. [58]

Such community-based investments are accompanied by effective conservation results. For example, in the Amazon between 2000 and 2015 deforestation was five times higher in areas outside protected areas and Indigenous territories despite the combined area of protected areas and Indigenous territories accounting for over one-half of the Amazon region. ${ }^{[146]}$ Preliminary research by TMP Systems provides additional evidence of the contributions of Community Conserved Areas (CCAs) in preventing deforestation, land-use change, and forest degradation (Figure 6.). Their analysis of forest cover change in protected areas and IPs', LCs', and ADs' territories covered 5.2 million $\mathrm{km}^{2}$ across nine countries and shows that between 2010 and 2018, comparable forest protection rates in CCAs were consistently higher than the national averages. In four countries (Brazil, Colombia, Zambia, and Venezuela) CCAs had lower deforestation rates than formally protected areas. In a further three countries (Costa Rica, Ecuador, and Panama), the deforestation rates in CCAs were comparable to those of formally protected areas, while lower in protected areas in Peru and Liberia (see Figure 6). 
The differences observed in Peru and Liberia could be attributed to underlying political dimensions which undermine rights and community initiatives that conserve commons. In Peru, even with frameworks for rights recognition, government actions actively undermine collective rights by granting oil, mining, and natural gas concessions. ${ }^{[139]}$ In Liberia, in the wake of a national moratorium on large-scale concessions and pervasive corruption, logging companies have "hijacked" weak community forest laws to gain access to community forests. ${ }^{[147]}$

Figure 6 Average annual rate of forest cover loss (2010-2018)

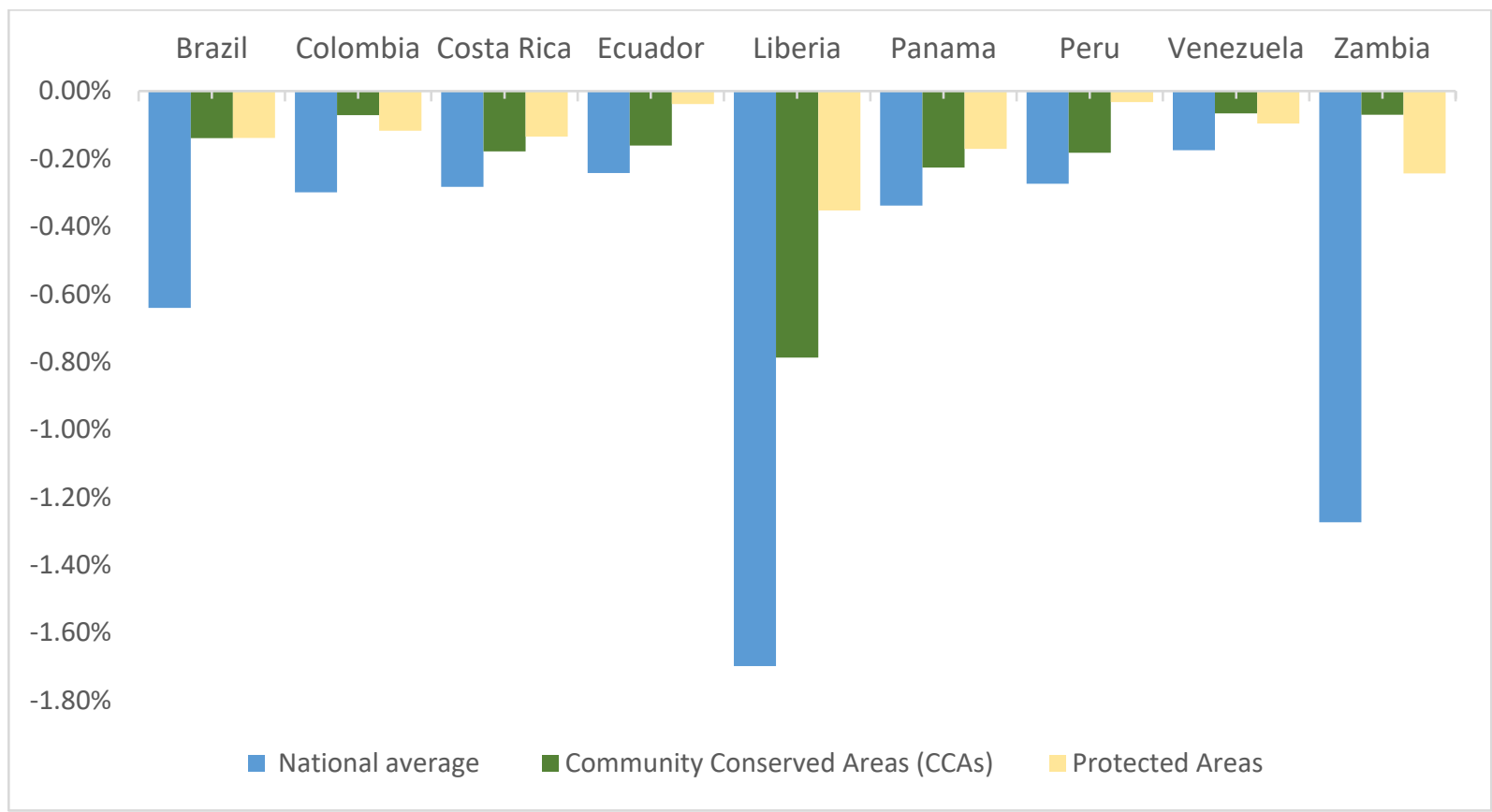

Caption: Using the percentage of forest cover loss per year, Figure 8 shows that lands managed by IPs, LCs, and ADs (Green) achieve comparable deforestation rates to Protected Areas (Yellow) and much lower deforestation rates than national average deforestation (Blue) [Annex]. Results include mapped community lands that are customarily managed without formal legal recognition. [Annex].

\section{Box 3: Preliminary findings from comparison of deforestation rates: need for more rigorous analysis}

In this study, the CCA maps were obtained from national institutions and non-governmental organizations. The majority of CCA polygons covered were legally recognized, but many CCAs are in the process of being claimed. No uniform data was available about communities' capacities of enforcement and forest conversion prevention. ${ }^{[139]}$ This study used net forest loss, which would not account for regenerative agricultural practices such as rotational farming or even forest fires, and as a result differences between protected areas and CCAs could be substantially less. When accounted for, such as in Walker et al.'s study on forest conversion across the Amazon basin, it was shown that Indigenous territories experienced a net change in carbon of 0.1 percent while protected areas experienced a net loss of 0.6 percent. ${ }^{[140]}$

While TMP Systems' preliminary research does not use a regression analysis for land characteristics, such as remoteness or population densities, the results nonetheless suggest that 
CCAs are better at preventing land-use change than national forests. These conclusions are further corroborated by research in Brazil, ${ }^{[146,148-150]}$ Peru, ${ }^{[151]}$ the Amazon basin more generally, ${ }^{[134,136,140]}$ and the rest of the world. ${ }^{[139]}$ When rights are weak or nonexistent, the forests of IPs, LCs, and ADs are vulnerable to deforestation from external actors. ${ }^{[139]}$ Considering the investments communities make into the conservation of their commons, the positive conservation outcomes of IPS, LCs, and ADs-achieved at a minimal external cost and under precarious rights enforcement-suggest high efficiency and effectiveness in community-led management and governance of biodiversity. ${ }^{[146,148-}$ 150]

Ample evidence exists demonstrating that IPS, LCS, and ADs with secure tenure rights achieve similar if not better conservation outcomes than private or state-managed protected areas, ${ }^{[152]}$ doing so at a lower cost. ${ }^{[153]}$ IPs, LCs, and ADs seldom if ever receive the financial, political, and technical support granted to public or private conservation initiatives, nor the security of statesanctioned enforcement measures, ${ }^{[59]}$ and yet, as recognized by the growing bodies of climate and conservation research, ${ }^{477,61,152]}$ their ability to sustainably manage and steward their lands and territories has so far remained strong. The relationship between IPS, LCs, and ADs with their territories of life goes beyond human stewardship of nature as the relationship is reciprocal, integrating livelihood, energy, and health, with identity, culture, autonomy, and freedom for the entire "territory of life" which connects the ancestors of the past and future generations yet to come with the actions of today. ${ }^{[31]}$ Conservation can therefore play a role in protecting both the environment and the rights of IPs, LCs, and ADs who collectively steward them. ${ }^{[154]}$

In the absence of secure collective rights over traditional lands and resources, ${ }^{[100]}$ rapid expansion of strictly managed or exclusionary conservation strategies risks generating inequality, human rights abuses, and conflicts over land. ${ }^{[98,}$ 155] Without the holistic and culturally appropriate integration of scientific and traditional ecological knowledge systems into global policy frameworks, reductionist technocratic conservation approaches could prevail. If this is to happen, state power may be further consolidated through increasingly militarized conservation strategies and harsh policies. ${ }^{[156]}$ These "tough-on-crime" policies are found to be ineffective in preventing or disincentivizing wildlife crime. ${ }^{[157]}$ As a result, these strategies would perpetuate historical injustices at the detriment of rural livelihoods ${ }^{[158,159]}$ and food security ${ }^{[68]}$ for hundreds of millions of already marginalized people across the world.

In contrast, inclusive strategies, and rights-based approaches more generally, are central to achieving conservation goals ${ }^{[114]}$ and landscape restoration ${ }^{[160,161]}$ targets. Working with rural communities to successfully combat wildlife crime and the trafficking of threatened species is a growing modelxii for the successful integration of local actors within global conservation priorities. ${ }^{[162,163]}$ The integration of traditional knowledge with formal scientific knowledge is increasingly recognized as vital for effective and equitable conservation outcomes. ${ }^{[164-166]}$ In fact, biocultural diversity is intrinsically linked to, ${ }^{[167]}$ and has actively helped create, ${ }^{[43,44,168,169]}$ biodiversity. 
A re-working of how conservation is done, from a focus solely on 'nature' to that which embraces the deep interdependence between local cultural heritage and the environment-labelled biocultural conservation ${ }^{\text {xii }}$-is gradually being recognized as vital for effective and equitable conservation outcomes. ${ }^{[164,165]}$ The contributions of biocultural conservation go beyond practical solutions by integrating Indigenous and local morals and relationships into conservation. For example, the notion of "living well," suma qamaña in Aymara and Buen vivir in Spanish, is only possible as a part of a community composed of both humans and non-humans. ${ }^{[170]}$ With biocultural conservation new ideas which counter market-based incentives for protecting nature and reject the notion that nature and humans are separate are emerging. ${ }^{[171]}$ Rather than "protect nature from humans," biocultural conservation promotes ways to con vivir (live with) nature by "promot[ing] nature for, to and by humans" and with it the myriad of human expressions that make traditional ecological knowledge. ${ }^{[171]}$ It is this relationship between IPs, LCs, and ADs to the non-human world, which do not separate culture and nature, that provides a powerful framework for future global and national environmental policies. These frameworks are gradually becoming popularized through emerging conceptual conservation frameworks, such as convivial conservation, ${ }^{[171]}$ which are built on the premise of equity, structural change, and environmental justice. ${ }^{[172]}$ The decentralization of conservation through locally-led biocultural conservation initiatives has also effectively revitalized dwindling species populations in a way that is led by local worldviews and values, and sustainably upholds such connections. ${ }^{[144]}$

Despite growing recognition of the need for inclusive governance and legislative procedures that are informed or led by the communities themselves, ${ }^{[98]}$ the development of institutional frameworks often takes place in power relations that tend to exclude IPS, LCs, and ADs in the drafting and formulation of laws aimed to protect their ancestral homes and the environment. ${ }^{[173,}$

174] Consequently, the recognition of rights under prevailing political conditions does not always guarantee that rights will be respected or protected against vested interests. ${ }^{[175]}$ Hence, understanding the conditions that support the recognition, absence, or skewed expression of rights is essential for the successful and just application of rights-based conservation strategies. ${ }^{\text {xiv }}$ Failing to do so will render communities, their struggle and relationships with traditional lands invisible ${ }^{[176]}$ in the global fight to "protect" the planet's remaining biodiversity. ${ }^{[177]}$

\section{Finding 5: Recognizing the traditional and customary lands of IPs, LCs, and ADs will substantially contribute to, or even exceed, area-based conservation targets}

To reiterate, IPs, LCs, and ADs are estimated to have grounded claims to over half of the planet's terrestrial area, however, their ownership rights are recognized on 10 percent of the planet's terrestrial area. ${ }^{[53]}$ Most land recognized are concentrated in a few countries in the Americas, which are increasingly being undermined by legislative rollbacks and mining activities which now cover 20 percent of Indigenous territories in the Amazon. ${ }^{[178]}$ In a majority of the countries critical for biodiversity conservation, the traditional territories and lands claimed by communities remain largely unrecognized. ${ }^{[54]}$ An analysis of 10 high conservation priority low- and lower-middle income countries show that 49 percent of the combined area of these countries is claimed as the collective 
territories of IPS, LCS, and ADs. Of these, only 8 percent have been legally recognized. ${ }^{[54]}$ In DRC, even though 86 percent of the land area is estimated to be claimed by IPS and LCs, only 0.53 percent of the country has any collective legal recognition. ${ }^{[54]}$ A similar situation exists in other important biodiversity countries such as Indonesia, India, Cameroon, and Myanmar. ${ }^{[54]}$ Due to the large overlaps between the important biodiversity conservation areas and the lands claimed by IPS, $L C s$, and $A D s,{ }^{[55]}$ supporting the rights-recognition processes in these countries is critical for achieving conservation targets without further marginalization. Ideally, rights-recognition processes should also result in collective restorative justice for millions of people.

\section{Box 4: Recognizing land rights across Africa to achieve conservation targets}

In Cameroon, the Central African Republic (CAR), DRC, Gabon, Kenya, Madagascar, the Republic of the Congo, and Sudan the unrecognized lands of IPs and LCs surpass the minimum land area (Scenario 1) for conserving biodiversity (Figure 8). In these countries, implementing conservation through inclusive community rights-based approaches could not only benefit biodiversity protection but the livelihoods of millions.

Figure 8: The area of IP and LC lands, both recognized and unrecognized, against the areas of formally protected areas and important conservation areas as a proportion of a country's total area

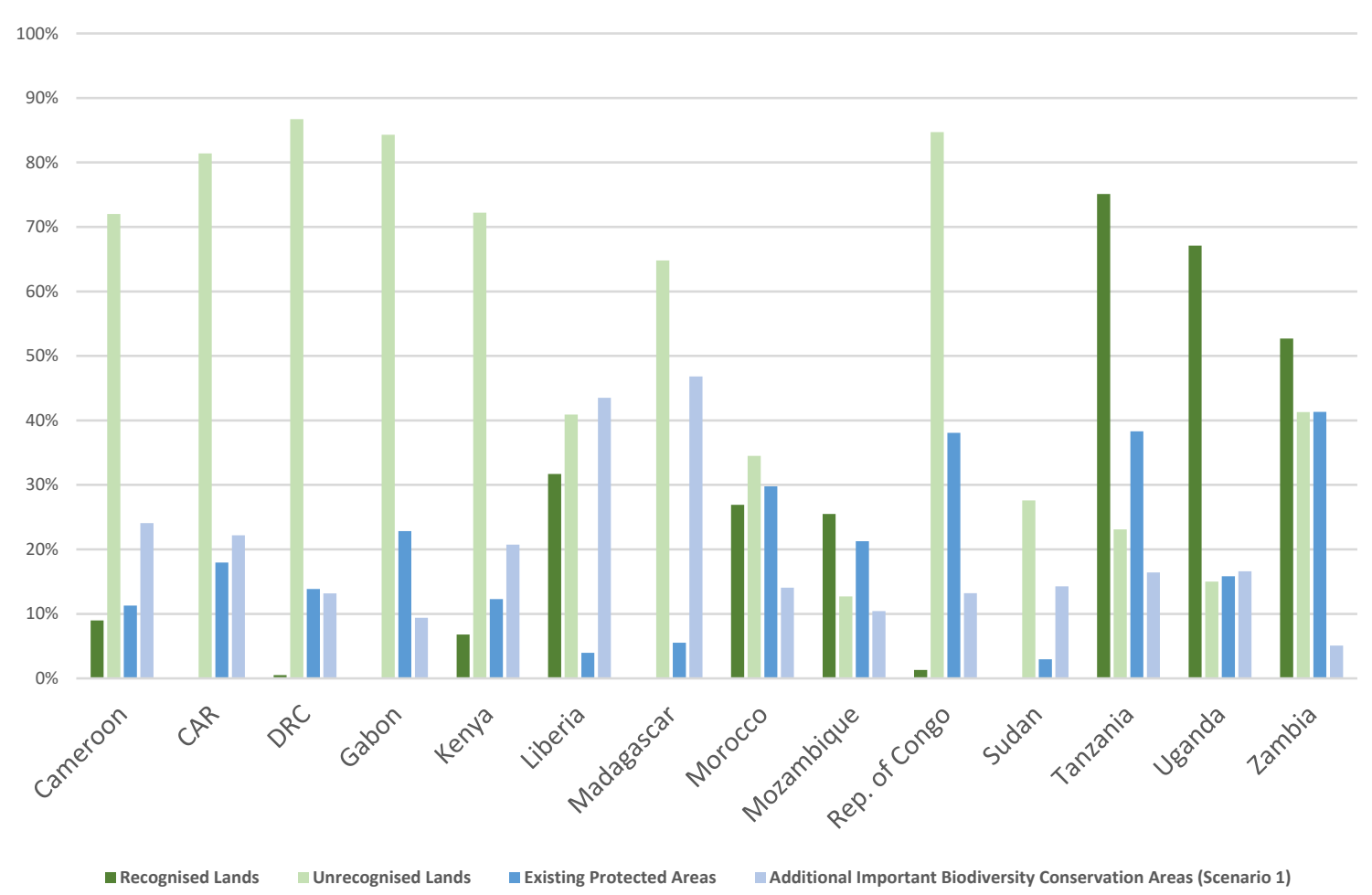

Across the 14 African countries analyzed in RRIs area estimate, the combined area of recognized and unrecognized IP and LC lands (Green) exceeds those of existing protected areas and important biodiversity conservation areas (Blue). The extent to which the recognized and unrecognized lands of IPs and LCs in these countries overlap with additional important biodiversity conservation areas is unknown, though substantial overlaps exist. 
Recognizing the land and resource rights of IPS, LCS, and ADs will contribute considerably to achieving area-based conservation targets. Across 43 countries studied in a recent publication by RRI, almost 1,488 million hectares of lands customarily claimed by IPs, LCs, and ADs remain unrecognized. ${ }^{[54]}$ In 11 of these countries, the area of unrecognized land surpasses the minimum land area identified for conserving biodiversity. ${ }^{[7,54]}$ For reference, Box 4 compares the areas claimed by IPs, LCS, and ADs and the important biodiversity conservation areas in 14 countries in Africa.

The argument for community rights-based conservation becomes even stronger when the costs for recognizing land and territorial rights are considered. In a number of high conservation potential countries, the data on the cost of $I P, L C$, and $A D$ rights recognition is available from the Tenure Facility ${ }^{x v}$ and ranges between $\$ 3$ to $\$ 11$ per hectare. A comparison between the cost of recognizing rights against the notional cost for compensating communities for resettlement in these countries shows that financial investments in rights recognition would be a miniscule fraction of the cost of excluding communities. Though our compensation calculations assume a worst-case scenario of resettling everyone living within important biodiversity conservation areas, it demonstrates that even resettling a very small fraction of the people (less than 1 percent) could still outweigh the costs of recognizing all lands claimed by IPs, LCs, and ADs in these countries. Compensating even a quarter, or a tenth, of the households in these areas is infeasible with current conservation budget estimates. ${ }^{[100]}$ This table uses Scenario 1 as a reference for conservation attention [Annex].

Table 5: The average cost of recognizing rights across five countries vs resettling under Scenario 1

\begin{tabular}{|l|c|c|c|c|c|c|} 
Country & $\begin{array}{c}\text { Cost for rights } \\
\text { recognition } \\
\text { per hectare } \\
\text { (US\$) }\end{array}$ & $\begin{array}{c}\text { Unrecognized } \\
\text { lands } \\
\text { (Million ha) } \\
\text { [128] }\end{array}$ & $\begin{array}{c}\text { Cost for } \\
\text { rights } \\
\text { recognition } \\
\text { (US\$ Billions) }\end{array}$ & $\begin{array}{c}\text { Area under } \\
\text { Scenario 1 } \\
\text { (Million ha) }\end{array}$ & $\begin{array}{c}\text { Total } \\
\text { population in } \\
\text { Scenario 1 } \\
\text { (Millions) }\end{array}$ & $\begin{array}{c}\text { Notional Cost of } \\
\text { resettling all } \\
\text { people living in } \\
\text { Scenario 1 } \\
\text { (US\$ Billion) }\end{array}$ \\
\hline Peru & 3.1 & 26.87 & 0.08 & 52.2 & 11.4 & 41.07 \\
\hline Indonesia & 3.7 & 39.2 & 0.15 & 67.6 & 94.3 & 323.04 \\
\hline India & 6.2 & 62.52 & 0.39 & 60.4 & 241.2 & 688.32 \\
\hline Nepal & 10.2 & 4.63 & 0.05 & 3.9 & 9.6 & 30.01 \\
\hline Liberia & 11 & 3.94 & 0.04 & 4.2 & 1.6 & 4.42 \\
\hline
\end{tabular}

Opportunities to scale up rights recognition of land and territories of IPS, LCs, and ADs exist in many countries. Another RRI report that measured the opportunities for recognizing tenure rights in 29 countries looked at the existing legal frameworks, political will, and local capacities for rights recognition of IPs, LCS, and ADs. ${ }^{[179]}$ This study found that in 10 of the 29 countries, the frameworks are in place to carry out nationwide rights recognition processes, ${ }^{[179]}$ including in conservation priority countries such as DRC, Indonesia, and India. In the remaining 19 countries, the conditions are conducive to supporting medium- and smaller-scale rights recognition processes. ${ }^{[179]}$ The collective findings within these reports demonstrate that the realization of community rights-based conservation is feasible and that opportunities for improving land and resource rights recognition exist in many countries. 
While these costs depict a notional financial value for recognizing rights versus the displacement and compensation of communities, recognizing rights represents the first stage in igniting transformative change by supporting the commons and trust in the communities who traditionally manage them to provide equitable solutions. ${ }^{[180,181]}$ By incorporating the agency and value systems of communities, by means of secure and inalienable collective rights regimes, new and novel ways of decentralizing financial benefits for sustainable traditional activities can be realized which not only acknowledge but reward the "services" provided by traditional governance regimes. As demonstrated in previous findings, IPs, LCS, and ADs provide practical and material benefits for effective environmental governance. However, the benefits transcend mere quantifiable conservation outcomes in how the inclusion and empowering of communities engenders the integration of other systems of valuing, and relating to, the natural world. [181]

\section{Conclusion: Conservation goals can be achieved through community rights- based conservation}

The above findings clearly indicate that meeting biodiversity targets requires recognizing the agency of IPs, LCs, and ADs in conserving biodiversity rich landscapes through rights-based approaches. Preventing irreversible biodiversity collapse can only be possible if the 1.64 to 1.87 billion people living in important biodiversity conservation areas mobilize and lead biodiversity conservation. The alternative of continuing with the current dominant paradigms of exclusionary conservation is financially infeasible, unjust, and would create large-scale conflicts and suffering.

IPs, LCs, and ADs claim 50\% of the earth's terrestrial area as their customary lands and territories, which widely overlaps with the important biodiversity conservation areas. Evidence presented in this report shows the effectiveness of community led conservation. They can effectively govern and protect these areas only if their jurisdiction over these areas are recognized and respected. Their rights have been formally recognized on only a fraction of the claimed lands in a few countries. IPs, LCs, and ADs have been trying to protect their customary territories and lands, often in the face of hostile state actors and other outsiders, as illustrated by the continued killing and criminalization of environment, land, and human rights defenders. ${ }^{[182]}$

Rights recognition is a prerequisite to ensure that IPs, LCs, and ADs have the right and authority to protect and conserve their lands and territories through their own self-determined governance strategies and local ecological knowledge ${ }^{[183]}$. As discussed above, recognizing rights at scale is feasible and cost effective, and can catalyze community rights-based conservation for conservation and protection of biodiversity. This pathway likely represents the core strategy for scaling up conservation to prevent biodiversity collapse. For conservation organizations and others trying to protect global biodiversity, supporting rights recognition of IPs', LCs', and ADs' rights and governance over important biodiversity landscapes provides an opportunity to achieve area-based conservation targets. 
Yet, community rights-based conservation remains marginal in global- and national-level conservation discourses. Conservation infrastructure and institutions remain top-down, dominated by bureaucracies and private actors, and the agency, contribution, and voice of local communities continue to be unrecognized, particularly in low- and lower-middle-income countries. In the current situation, without explicit community rights-based strategies and safeguards, there is a danger that the international application of area-based conservation strategies will focus on strict biodiversity protection measures (i.e. exclusion), while failing to address the true drivers of biodiversity loss. ${ }^{[184-}$ ${ }^{186]}$ It is also likely that global conservation efforts will continue to miss vital biodiversity targets as they have done this past decade. ${ }^{[63]}$

In spite of increasing recognition of these problems with conservation strategies, global conservation funding and support remains largely committed to top-down conservation led by conservation bureaucracies and large northern-based conservation NGOs. It is also increasingly focusing on financialization of conservation and market-linked nature-based solutions. Without recognizing the rights of IPS, LCs, and ADs and without proper safeguards, such approaches pose high risks to these communities. Elite capture of financial flows and market-based mechanisms by national bureaucracies and powerful private sector actors is likely to occur, accompanied by increased militarization of conservation, dispossession, conflicts, and human and resource rights violation of IP, LCS, and ADs. As global experience and documentation shows, communities inhabiting important biodiversity conservation areas in low- and lower-middle income countries with poor governance, low transparency, and poor human rights records face the highest risks. The global conservation organizations and government donors from high income countries are the major drivers of global conservation efforts in these countries and it is incumbent on them to take the lead in shifting the paradigm of conservation towards inclusive strategies led by communities.

The larger processes threatening the environment and biodiversity are often the same as those threatening communities and their ways of life. IPs, LCs, and ADs have been trying to protect their customary territories and lands in the face of hostile state and non-state actors for years, as illustrated by the continued killing and criminalization of environment, land, and human rights defenders. ${ }^{[182]}$ Failing to address dynamics of power within conservation decision-making and the impacts of centralized governance and management regimes on IPs, LCs, and ADs across the world would be counterproductive to conservation's agenda. ${ }^{[25,107,114,171,183]}$ Recognition of the collective rights of IPs, LCs, and ADs is a prerequisite to ensure that they have the right, agency, and authority to protect and conserve their lands through their own self-determined governance strategies and local ecological knowledge. ${ }^{[183]}$

As discussed in the recommendations, there are a number of commitments which can be made by the global actors for promoting community led rights-based conservation. There is a need to shift global conservation infrastructure, institutions, and funding to a rights-based and inclusive conservation approach, including in the ongoing CBD processes. As conservation remains largely driven by global priorities and funding, the international donors and conservation organizations need to take the responsibility of effecting this change and ally with the IPS, LCs, and ADs for rights- 
based conservation. This report has put together the evidence for adopting rights-based conservation and framing it as the alternate pathway for just and sustainable conservation. The responsibility of taking this path rests with all those who seek to reverse biodiversity collapse, while avoiding the moral hazards of business-as-usual conservation.

\section{Annex: Methodology}

\section{Mapping important biodiversity areas and priority conservation areas}

The spatial data of existing protected areas was obtained from the 2020 version of the World Database on Protected Areas (WDPA), however, the data on protected areas in China is from the 2017 version which is the latest for that country. ${ }^{[65]}$ As directed in the WDPA user manual, the existing legally recognized terrestrial protected area estate was calculated by excluding all "proposed" protected areas, UNESCO Man and Biosphere Reserves (MABs), and all marine protected areas. ${ }^{[184]}$ The September 2019 version of the World Database of Key Biodiversity Areas ${ }^{[64]}$ was used, containing data from 15,610 KBAs. For point data in both WDPAs and KBAs polygons were calculated using a geodesic buffer created in accordance to the point's areal attributes. ${ }^{[7]}$ These layers were provided by Allan, et al., ${ }^{[7]}$ and a more detailed methodology can be found in the same.

The extent of lands free from the pressures of modern society, or 'wilderness areas', were provided by Allan, et al., 2017. ${ }^{[32]}$ Existing protected areas were erased from the KBA layer to remove overlaps and both KBAs and existing protected areas were erased from wilderness areas to identify important unprotected conservation areas.

We used three maps developed by Allan et al., ${ }^{[7]}$ which combined existing protected areas with sitebased approaches (Key Biodiversity Areas), ${ }^{[185]}$ proactive approaches (wilderness areas), ${ }^{[35]}$ and prioritizations that ensure a suitable portion of more than 28,000 terrestrial species ranges are covered, therefore identifying areas requiring conservation attention. These terrestrial species ranges of mammals, birds, amphibians, reptiles, dragonflies, and crustaceans, ${ }^{[186-188]}$ and include ecoregions. ${ }^{[189]}$ The prioritization is an efficiency-based planning approach which maximizes the number of species or ecosystems captured within a collection of conservation areas, prioritizing species and ecosystems by their endemicity, extinction risk, and their degree of representation (represented or underrepresented) in existing protected areas. Combining these area-based approaches ensures that species and earth-systems are both adequately represented to ensure species persistence as well as the persistence of intact ecosystems important for biodiversity. ${ }^{[190]}$

The three prioritization scenarios secured all important conservation areas and terrestrial species ranges while a) minimizing the land area required (Scenario 1); b) minimizing overlap with human populations and infrastructure (human footprint) (Scenario 2); and c) minimizing overlap with agriculturally suitable lands ${ }^{[191]}$ (Scenario 3). This analysis is the most comprehensive estimate of the minimum land area requiring conservation attention to prevent the collapse of biodiversity. ${ }^{[7]}$ 
Existing protected areas ${ }^{[65]}$ were subsequently erased to provide a layer combining ecoregions, biodiversity hotspots and important ranges of terrestrial wildlife not formally protected under the IUCN's management categories. ${ }^{[30]}$

KBAs, wilderness areas, and existing protected areas overlap. ${ }^{[7]}$ When considering these overlaps, KBAs will only contribute an additional $3.87 \%$ of the planet's terrestrial area to expanding protected areas (with 245 million people within them) while wilderness areas will contribute an additional 19\% (with 1.83 million people). We removed all existing protected areas from KBAs and both KBAs and protected areas from wilderness areas to gain these numbers. These layers are dynamic, increased "modern" human activities put increasing pressure on wilderness areas, ${ }^{[33]}$ and KBAs have only been identified for bird species ${ }^{[64]}$ and are expected to expand and incorporate other taxa in the coming years.

This report has not analyzed marine protected areas as population distribution data is incapable of addressing issues of the use, access, and management of water bodies and their resources. Though water rights, and issues of access to water related resources, are relevant in the conservation debate, these issues are beyond the scope of our methodology and will require further research. Secure and clearly defined community-based water tenure regimes are also essential for IPs', LCs', and ADs' livelihoods and food security, as well as to a country's efforts to achieve sustainable development priorities and ensure climate resilience. ${ }^{[87]}$ This is true for the equitable governance of all water bodies, such as fresh water bodies ${ }^{[87]}$, mangroves ${ }^{[192,193]}$, and fisheries, and emphasizes the need to implement "rights-based fishing" to strengthen community rights of access to fishery resources. ${ }^{[194,195]}$ The findings in this report can be applied for the equitable management of water bodies by IPS, LCS, and ADs.

\section{Integrating important biodiversity conservation areas and people}

We used LandScan's global population distribution model for the year 2018 ${ }^{[66]}$ to estimate the number of people living within current and proposed conservation areas. Our methodology expanded on that of Schleicher et al., who used LandScan to measure the populations living in the least populated ecoregions. ${ }^{[196]}$ Data were extracted to estimate the area and number of people found within existing protected areas, ${ }^{[65]}$ Key Biodiversity Areas, ${ }^{[64]}$ Wilderness Areas, ${ }^{[32]}$ the three scenarios, ${ }^{[7]}$ as well as their combined total area. These were then tabulated using the database of Global Administrative Areas (GADM 2020) to provide measures for each territory. Population data were calculated in raster format at a resolution of 30 by 30 arc seconds, approximately $1 \mathrm{~km}^{2}$ $\left(835 \mathrm{~m}^{2}\right)$. LandScan population data represents an ambient population (average over 24 hours) distribution as approximately $1 \mathrm{~km}, 835$ meters $^{2},\left(30^{\prime \prime} \times 30^{\prime \prime}\right)$ spatial resolution. Though represented as blue, it is important to note that wilderness areas are inhabited and not without humans, these landscapes are home to IPs, LCs, and ADs, pastoralists, nomadic peoples, and more and should not be assumed to be without all aspects of human life, culture and society. ${ }^{[32,197,198]}$ All calculations were performed using the Mollweide equal area projection and ArcGIS ${ }$ software. ${ }^{[199]}$ 
Once tabulated, data from Antarctica and Vatican City were excluded from spatial and population calculations. All overseas territories were prescribed to their respective administrative country before associating each administrative country, and corresponding territories, to their respective income status. Income status data was obtained using the World Bank Group's List of Economies Database. ${ }^{[67]}$ Where available, the average household size was attributed to the corresponding country, using the United Nations Department of Economic and Social Affairs Population Division's ‘Household Size and Composition Around the World 2017 Data Booklet.[200]

\section{Calculating notional compensation costs}

There are ethical and moral considerations to attributing a monetized value to the resettlement or relocation of communities, whether voluntarily or involuntarily. Any form of involuntary relocation ignores the fundamental right of IPs, LCS, and ADs to free, prior and informed consent and the fundamental right to withhold consent. The Rights and Resources Initiative does not advocate for monetary forms of compensation for "relocating," "resettling," or displacing IP, LC, and AD communities who have deep and integrated connections with their socio-ecological environments. This research has refrained from attaching a monetary value on compensating communities, instead using only the notional cost of physical relocation to present a conservative estimate and indicative cost of conservation induced resettlement to estimate the financial implications of a frequently proposed strategy which is not fully understood within policy.

Applying compensation costs is an exercise in quantifying the feasibility of this proposed conflict mitigation strategy. There are non-monetizable values held between communities and their socioecological systems that cannot, and should not, be valued through a financial lens. No value can be attached to shared histories and the spiritual connections between communities and spaces, which are themselves sacred. The calculations within this report are not an attempt to estimate compensation values and has, by design, excluded a number of important variables.

This report has used "involuntary resettlement" and the provisions of compensation as defined by the World Bank Group's OP 4.12. ${ }^{[105]}$ Over 50 resettlement action plans (RAPs) were analyses to find a lump compensation sum that could be directly ascribed to the "unit of entitlement" of a household. Only ten RAPs were selected, due to containing this lump sum payment which could be attributed to a household. These 10 RAPs spanned 11 low-, lower-middle-, and upper-middleincome countries. The average lump notional resettlement sum was found to be USD\$5615, USD $\$ 12,281$, and USD $\$ 23,195$ for low-, lower-middle-, and upper-middle-income countries respectively. These were averaged to provide a notional per household physical resettlement compensation of USD $\$ 13,697$. The populations within layers were divided by the average global household size (4.2 people per household), before multiplying the estimated number of households by the average compensation cost.

A number of assumptions have been made in order to calculate these cost estimates. First and foremost, the unit of compensation entitlement was assumed to be a household. Due to limitations in the methodology, this calculation does not account for individuals, single parent households, 
households of persons with disabilities and those who would require particular assistance and warrant increased compensation rates. [Annex]. Household compensation rates were taken from 10 RAPs, across 11 low-, lower-middle, and upper-middle-income countries, which were averaged to provide this minimal compensation cost for relocating households.

\section{Even this notional exercise remains a massive underestimate as this methodology has:}

- Not calculated compensation for economic displacement due to the loss of livelihood of people living in targeted areas;

- Not calculated the compensation for economic displacement due to the loss of livelihood associated to restrictions on the access to natural resources by those living outside targeted areas;

- Excluded the cost of compensating land, loss of buildings (schools, shops, houses), fruit trees, administrative costs, social programs to support a just transition, logistical costs associated to resettlement, loss of livelihood and broader economic displacement etc.;

- Excluded extra compensation costs within the selected RAPs which could not be linked to a household;

- Not used RAPs from high-income countries, which would be higher;

- Assumed the global unit of entitlement to be a household. In doing so this calculation has not included the costs associated to compensating individuals, single parent households, or the needs of disabled peoples within a community. In doing so, from each RAP, only the costs directly associated to a household were used. Compensation is often provided on a basis of land area lost per household linked to the cost of land. Total compensation was consequently averaged over the total households impacted as opposed to the average cost per hectare of land each household had;

- Not included nor attached a monetized value to non-monetizable resources, knowledge or relationships.

The calculation was carried out only to illustrate the magnitude of potential financial costs if exclusionary conservation is the main strategy for expansion of protected areas and is a thought experiment. RRI strongly opposes resettlement or removal of IPs, LCs, and ADs from their lands for conservation.

\section{Calculating forest cover change}

TMP Systems used the Global Forest Change (GFC) dataset, which measures tree cover loss at a resolution of 1 arc-second, measuring deforestation from the baseline tree cover of 2010. ${ }^{[201]}$ They measured annual tree cover loss as a decrease in tree cover by $30 \%$ over a $30-$ meter $^{2}$ resolution in 9,179 parcels across 10 countries. The deforestation rate was calculated as the annual cumulative rate of change. ${ }^{[202]}$ TMP received CCA data from LandMark, ${ }^{[203]}$ Global Forest Watch, ${ }^{[204]}$ Indigenous organizations, and governmental databases. These included mapped lands without legal recognition as IPS, LCS, and ADs often have de facto rights to their lands in the absence of government. 


\section{About the Rights and Resources Initiative}

The Rights and Resources Initiative is a global Coalition of more than 200 organizations dedicated to advancing the forestland and resource rights of Indigenous Peoples, Afro-descendants, local communities, and women within these communities. Members capitalize on each other's strengths, expertise, and geographic reach to achieve solutions more effectively and efficiently. RRI leverages the power of its global Coalition to amplify the voices of local peoples and proactively engage governments, multilateral institutions, and private sector actors to adopt institutional and market reforms that support the realization of rights. By advancing a strategic understanding of the global threats and opportunities resulting from insecure land and resource rights, RRI develops and promotes rights-based approaches to business and development and catalyzes effective solutions to scale rural tenure reform and enhance sustainable resource governance.

$\mathrm{RRI}$ is coordinated by the Rights and Resources Group, a non-profit organization based in Washington, DC. For more information, please visit www.rightsandresources.org.

\section{Partners}

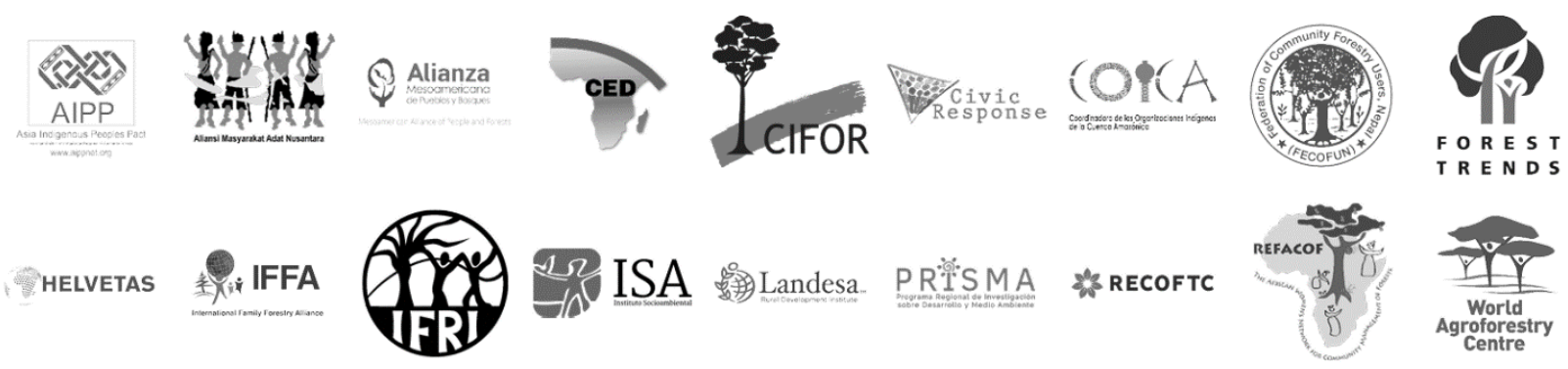

\section{Sponsors}

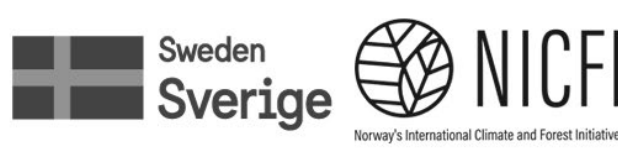

\section{NT/}

The views presented here are not necessarily shared by the agencies that have generously supported this work. This work is licensed under a Creative Commons Attribution License CC BY 4.0. 


\section{Bibliography}

1. Woodley, S., et al., Area-based conservation beyond 2020: A global survey of conservation scientists. Parks, 2019(25.2): p. 1930 .

2. Woodley, S., et al., A review of evidence for area-based conservation targets for the post-2020 global biodiversity framework. Parks, 2019(25.2): p. 31-46.

3. Dinerstein, E., et al., An Ecoregion-Based Approach to Protecting Half the Terrestrial Realm. Bioscience, 2017. 67(6): p. 534545.

4. Dinerstein, E., et al., A Global Deal For Nature: Guiding principles, milestones, and targets. Sci Adv, 2019. 5(4): p. eaaw2869.

5. Wilson, E.O., Half-Earth: Our Planet's Fight For Life. 2016, New York: Liveright Publishing Corporation.

6. Locke, H., Nature Needs Half: A necessary and hopeful new agenda for protected areas. . Parks 2013. 19: p. 9-18.

7. Allan, J.R., et al., Conservation attention necessary across at least 44\% of Earth's terrestrial area to safeguard biodiversity. Nature, 2020

8. UN Secretary-General. 2016. Report of the Special Rapporteur of the Human Rights Council on the rights of indigenous peoples, Victoria Tauli-Corpuz. 71st session of the UN General Assembly,16 July 2016. A711/229.

9. UNDP, Draft Investigation ReportInvestigating allegations of non-compliance with UNDP social and environmental commitments relating to the following UNDP activities:Integrated and Transboundary Conservation of Biodiversity in the Basins of the Republic of Congo, TRIDOMII.(October 2017 -March 2023) Case No. SECU0009, in United Nations Development Programme-OAl, Social and Environmental Compliance Unit 2020, UNDP.

10. Rights and Resources Initiative, Cornered by Protected Areas: Replacing 'Fortress' Conservation with Rights-based Appproaches Helps Bring Justice for Indigenous Peoples and Local Communities, Reduces Conflict, and Enables CosteffectiveConservation and Climate Action. 2018, Rights and Resources Initiative: Rights and Resources Initiative.

11. Brockington, D., J. Igoe, and K. Schmidt-Soltau, Conservation, human rights, and poverty reduction. Conserv Biol, 2006. 20(1): p. 250-2.

12. Chatty, D. and M. Colchester, Conservation and Mobile Indigenous Peoples: Displacement, Forced Settlement, and Sustainable Development. 2002: Berghahn Books.

13. Neumann, R.P., Imposing wilderness: struggles of livlihood and nature preservation in Africa. 1998, Berkeley, CA: University of California Press. Dowie, M., Conservation Refugees: The Hundred-Year Conflict between Global Conservation and Native Peoples. null. Vol. null. 2011: MIT Press. null.

15. Brockington, D. and J. Igoe, Eviction for Conservation: A Global Overview. Conservation and Society, 2006. 4(3): p. 424-470. Geisler, C., A new kind of trouble: evictions in Eden*. International Social Science Journal, 2003. 55(175): p. 69-78.

Geisler, C. and R. De Sousa, From refuge to refugee: the African case. Public Administration and Development, 2001. 21(2): p. 159-170.

18. Cernea, M., 'Restriction of Access' Is Displacement: A Broader Concept and Policy. Forced Migration Review, 2005 : p. $48-49$. Duffy, R., Waging a war to save biodiversity: the rise of militarized conservation. International Affairs, 2014. 90: p. 819-834. Duffy, R., et al., Why we must question the militarisation of conservation. Biological Conservation, 2019. 232: p. 66-73. Duffy, R. and International African Institute, Killing for Conservation: Wildlife Policy in Zimbabwe. 2000: International African Institute.

22. Lunstrum, E., Conservation Meets Militarisation in Kruger National Park: Historical Encounters and Complex Legacies. Conservation and Society, 2015. 13(4): p. 356-369.

23. Marijnen, E. and J. Verweijen, Selling green militarization: The discursive (re)production of militarized conservation in the Virunga National Park, Democratic Republic of the Congo. Geoforum, 2016. 75: p. 274-285.

24. Weldemichel, T.G., Othering Pastoralists, State Violence, and the Remaking of Boundaries in Tanzania's Militarised Wildlife Conservation Sector. Antipode, 2020. 52(5): p. 1496-1518.

25. Domínguez, L. and C. Luoma, Decolonising Conservation Policy: How Colonial Land and Conservation Ideologies Persist and Perpetuate Indigenous Injustices at the Expense of the Environment. Land, 2020. 9, 65.

26. Indigenous and Community Response, A Statement On The Intergovernmental Panel On Climate Change (IPCC) Special Report On Climate Change And Land From Indigenous Peoples And Local Communities* From 42 Countries Spanning 76\% Of The World'S Tropical Forests. Indigenous + Community Response to IPCC Report. 2019.

27. Sajeva, G., G. Borrini-Feyerabend, and T. Niederberger, Meanings and more... Policy Brief of the ICCA Consortium no. 7. 2019.

28. Farvar, M.T., et al., Whose Inclusive Conservation'? Policy Brief of the ICCA Consortium no. 5, in The ICCA Consortium and Cenesta. Tehran. 2018.

29. Barrow, E.G.C., et al., Community Conservation from Concept to Practice: A Practical Farmework. 1998: Institute for Development Policy and Management, University of Manchester. 
30. Dudley, N., et al., Guidelines for Applying Protected Area Management Categories. 2008: IUCN.

31. ICCA Consortium. Territories and areas conserved by indigenous peoples and local communities. 2020 [cited 2020; Available from: https://www.iccaconsortium.org/index.php/discover/.

32. Allan, J.R., O. Venter, and J.E.M. Watson, Temporally inter-comparable maps of terrestrial wilderness and the Last of the Wild. Sci Data, 2017. 4(1): p. 170187.

33. Watson, James E.M., et al., Catastrophic Declines in Wilderness Areas Undermine Global Environment Targets. Current Biology, 2016. 26(21): p. 2929-2934.

34. Mittermeier, R.A., et al., Wilderness and biodiversity conservation. Proceedings of the National Academy of Sciences, 2003. 100(18): p. 10309-10313.

35. Watson, J.E.M., et al., Protect the last of the wild. Nature, 2018. 563(7729): p. 27-30.

36. Lovejoy, T.E., Conservation Biology: The Importance of Wilderness. Current Biology, 2016. 26(23): p. R1235-R1237.

37. Thoreau, H.D. and S.A. Fender, Walden. 2008: OUP Oxford.

38. Muir, J., "Lessons of the Wilderness". 1912: Atlantic Monthly. 111: 8.

39. Roe, D., et al., "Evaluating Eden." Evaluating Eden Series. 2000, International Institute for Environment and Development: London, No 8.

40. Wuerthner, G., E. Crist, and T. Butler, Protecting the Wild: Parks and Wilderness, the Foundation for Conservation. 2015: Island Press.

41. Cronon, W., Uncommon Ground: Rethinking the Human Place in Nature. 1996: W. W. Norton.

42. Williams, B.A., et al., Change in Terrestrial Human Footprint Drives Continued Loss of Intact Ecosystems. One Earth, 2020. 3(3): p. 371-382.

43. Levis, C., et al., Persistent effects of pre-Columbian plant domestication on Amazonian forest composition. Science, 2017. 355(6328): p. 925-931. Oliveira, E.A., et al., Legacy of Amazonian Dark Earth soils on forest structure and species composition. Global Ecology and Biogeography, 2020. 29(9): p. 1458-1473.

45. Maezumi, S.Y., et al., The legacy of 4,500 years of polyculture agroforestry in the eastern Amazon. Nature plants, 2018. 4(8): p. 540-547.

Vadjunec, J., M. Schmink, and A. Greiner, New Amazonian Geographies: Emerging Identities and Landscapes. Journal of Cultural Geography, 2011. 28: p. 1-20.

47. IPBES, The global assessment report on biodiversity and ecosystem services, in Summary for policymakers. 2019.

48. Ceballos, G., et al., Accelerated modern human-induced species losses: Entering the sixth mass extinction. Sci Adv, 2015. 1(5): p. e1400253.

49. Bruner, A.G., et al., Effectiveness of parks in protecting tropical biodiversity. Science, 2001. 291(5501): p. 125-8.

50. Dudley, N., The essential role of other effective area-based conservation measures in achieving big bold conservation targets. . Glob. Ecol. Conserv. 1, 2018. 5: p. 1-7.

51. Watson, J.E.M., et al., Bolder science needed now for protected areas. Conservation Biology, 2016. 30(2): p. $243-248$.

52. UNEP-WCMC, IUCN, and NGS. Protected Planet Report 2018. 2018; Available from: https://livereport.protectedplanet.net/pdf/Protected Planet Report 2018.pdf

53. Rights and Resources Initiative, Who Owns the World's Land? A global baseline of formally recognized indigenous and community land rights. 2015, Rights and Resources Initiative: Washington, DC.

54. Rights and Resources Initiative, Estimate of the area of land and territories of Indigenous Peoples, local communities, and Afro-descendant Peoples where their rights have not been recognized. 2020, Rights and Resources Initiative: Washington D.C.

55. Garnett, S.T., et al., A spatial overview of the global importance of Indigenous lands for conservation. Nature Sustainability, 2018. 1(7): p. 369-374.

56. Fa, J.E., et al., Importance of Indigenous Peoples' lands for the conservation of Intact Forest Landscapes. Frontiers in Ecology and the Environment, 2020. 18(3): p. 135-140.

57. Stevens, S., et al., Recognising and Respecting ICCAs Overlapped by Protected Areas. 2016, ICCA Consortium: online.

58. Tauli-Corpuz, V., J. Alcorn, and A. Molnar, Cornered by Protected Areas. 2018, Rights and Resources Initiative: Washington, DC.

59. Tauli-Corpuz, V., et al., Cornered by PAs: Adopting rights-based approaches to enable cost-effective conservation and climate action. World Development, 2020. 130: p. 104923.

60. Forest Peoples Programme, et al., Local Biodiversity Outlooks 2: The contributions of indigenous peoples and local communities to the implementation of the Strategic Plan for Biodiversity 2011-2020 and to renewing nature and cultures. A complement to the fifth edition of Global Biodiversity Outlook. . 2020, Forest Peoples Programme: Moreton-in-Marsh, England.

61. IPCC, Climate Change and Land: an IPCC special report on climate change, desertification, land degradation, sustainable land management, food security, and greenhouse gas fluxes in terrestrial ecosystems. 2019, IPCC: IPCC.

62. United Nations Environment Programme and the Food and Agriculture Organization, The United Nations Decade on Ecosystem Restoration. 2020, UNEP \& FAO: Online.

63. Secretariat of the Convention on Biological Diversity, Global Biodiversity Outlook 5. Montreal. 2020, Montreal. 
64. BirdLife International, World Database of Key Biodiversity Areas (KBAs). Developed by the KBA Partnership. 2017.

65. UNEP-WCMC and IUCN, Protected Planet: The World Database on Protected Areas (WDPA). 2020: Cambridge, UK: UNEPWCMC and IUCN.

66. Rose, A.N., et al., 'LandScan 2018'. Oak Ridge, TN: Oak Ridge National Laboratory SE - July 1, 2019 (LandScan). 2019.

67. The World Bank Group, World Bank Country and Lending Groups - List of economies database. 2020, The World Bank Group: The World Bank Group.

68. Vasquez, W. and T. Sunderland, Protected Areas and Food Security: Unravelling the Issues, in Participatory Biodiversity Conservation: Concepts, Experiences, and Perspectives, C. Baldauf, Editor. 2020, Springer International Publishing: Cham. p. 53-68.

69. Alcorn, J. and A. Molnar, Violations of Indigenous Peoples' and Local Communities' Rights and Steps Toward Reform in 27 Countries. 2018: Rights and Resources Initiative.

70. Igoe, J. and D. Brockington, Fortress Conservation: The Preservation of the Mkomazi Game Reserve, Tanzania. The International Journal of African Historical Studies, 2002. 35: p. 594.

71. Brockington, D., Community Conservation, Inequality and Injustice: Myths of Power in Protected Area Management. Conservation and Society, 2004. 2(2): p. 411-432.

72. Schmidt-Soltau, K. and D. Brockington, Protected Areas and Resettlement: What Scope for Voluntary Relocation? World Development, 2007. 35: p. 2182-2202.

73. Basik, N., The Role of Women in Asia's Community Forest Enterprises. 2012, The Rights and Resources Initiative: Washignton D.C.

74. International Fund for Agricultural Development, Gender and non-timber forest productsPromoting food security and economic empowerment. 2008, IFAD: Rome, Italy.

75. Dinda, S., S. Ghosh, and N.D. Chatterjee, Understanding the Commercialization Patterns of Non-timber Forest Products and Their Contribution to the Enhancement of Tribal Livelihoods: An Empirical Study from Paschim Medinipur District, India. Smallscale Forestry, 2020. 19(3): p. 371-397.

76. Michael, P.W. and T.O. McShane, Integrating Protected Area Management with Local Needs and Aspirations. Ambio, 2004. 33(8): p. 513-519.

77. Oldekop, J.A., et al., Understanding the lessons and limitations of conservation and development. Conserv Biol, 2010. 24(2): p. 461-9.

78. Oldekop, J.A., et al., A global assessment of the social and conservation outcomes of protected areas. Conserv Biol, 2016. 30(1): p. 133-41.

79. Rights and Resources Initiative, At a Crossroads: Consequential Trends in Recognition of Comunity-Based Forest Tenure from 2002-2017. 2018, Rights and Resources Initiative: Rights and Resources Initiative, Wasington D.C.

80. Asfaw, A., et al., Importance, determinants and gender dimensions of forest income in eastern highlands of Ethiopia: The case of communities around Jelo Afromontane forest. Forest Policy and Economics, 2013. 28: p. 1-7.

81. Alex, A., V. Kattany, and P. Geethakutty, Gender Dimensions in NTFP Collection Among the Indigenous Communities of Western Ghats of India. 2016. 17: p. 24-32.

82. Urrieta, J.L., Indigenous Reflections on Identity, Trauma, and Healing: Navigating Belonging and Power. Genealogy, 2019. 3: p. 26.

83. Cohen, A. The Mental Health of Indigenous Peoples: An International Overview. 1999 [cited 2020; Available from: https://www.culturalsurvival.org/publications/cultural-survival-quarterly/mental-health-indigenous-peoplesinternational-overview.

84. Donald, P.F., et al., The prevalence, characteristics and effectiveness of Aichi Target 11's "other effective area-based conservation measures" (OECMs) in Key Biodiversity Areas. Conservation Letters, 2019. 12(5): p. e12659.

85. Agrawal, A., Forests, Governance, and Sustainability: Common Property Theory and its Contributions. International Journal of the Commons, 2007. 1(1).

86. Robinson, B.E., et al., Incorporating Land Tenure Security into Conservation. Conservation Letters, 2018. 11(2): p. e12383.

87. Rights and Resources Initiative and Environmental Law Institute, Whose Water? A Comparative Analysis of National Laws and Regulations Recognizing Indigenous Peoples', Afro-descendants', and Local Communities' Water Tenure., W. Rights and Resources Initiative, DC. , Editor. 2020, Rights and Resources Initiative, Washington, DC. .

88. Pandey, A., Y. Tripathi, and A. Kumar, Non Timber Forest Products (NTFPs) for Sustained Livelihood: Challenges and Strategies. Research Journal of Forestry, 2016: p. 1-7.

89. Kumar, K., N. Singh, and Y.G. Rao, Promise and performance of the forest rights act: A ten-year review. Economic and Political Weekly, 2017. 52: p. 40-43.

90. Rasul, G., M. Karki, and R. Sah, The role of non-timber forest products in poverty reduction in India: Prospects and problems. Development in Practice, 2008. 18: p. 779-788.

91. Shackleton, S., et al., Links between the Local Trade in Natural Products, Livelihoods and Poverty Alleviation in a Semi-arid Region of South Africa. World Development, 2008. 36(3): p. 505-526.

92. Chellam, R., How the conservation potential of FRA has been wilfully undermined, in DownToEarth. 2019, DownToEarth: online. 
93. Wilkie, D.S., et al., Parks and people: assessing the human welfare effects of establishing protected areas for biodiversity conservation. Conserv Biol, 2006. 20(1): p. 247-9.

94. Chapin, M.A.C., A Challenge to Conservationist. WorldWatch, 2004. 17.

95. Colchester, M., World Rainforest Movement, and World Wide Fund for Nature, Salvaging Nature: Indigenous Peoples, Protected Areas and Biodiversity Conservation. 1994: United Nations Research Institute for Social Development.

96. Grove, R.H., Green imperialism: colonial expansion, tropical island Edens and the origins of environmentalism 1600-1860. null. Vol. null. 1996. null.

97. Cernea, M.M. and K. Schmidt-Soltau, Poverty Risks and National Parks: Policy Issues in Conservation and Resettlement. World Development, 2006. 34(10): p. 1808-1830.

98. Rights and Resources Initiative, Protected Areas and the Land Rights of Indigenous Peoples and Local Communities. 2015, Rights and Resources Initiative.

99. Brockington, D. and D. Wilkie, Protected areas and poverty. Philos Trans R Soc Lond B Biol Sci, 2015. 370(1681): p. 20140271.

100. Waldron, A., et al., Protecting 30\% of the planet for nature: costs, benefits and economic implications. Campaign for Nature, 2020.

101. Tagliarino, N., Avoiding the Worst Case Scenario Whether Indigenous Peoples and Local Communities in Asia and Africa are Vulnerable to Expropriation Without Fair Compensation. World Bank Land and Poverty Conference Paper 2017, 2017.

102. African Development Bank Group, Involuntary Resettlement Policy. 2003, African Development Bank Group: African Development Bank Group.

103. Asian Development Bank, A Planning and Implementation Good Practice Sourcebook - Draft Working Document. Involuntary Resettlement Safeguards. 2012, Manila: Asian Development Bank: Manila: Asian Development Bank.

104. International Union for Conservation of Nature, Standard on Involuntary Resettlement and Access Restrictions: Resettlement Action Plan (RAP). 2018: International Union for Conservation of Nature,.

105. World Bank Group, Operational Policy 4.12: Involuntary Resettlement. 2001: World Bank, Washington, DC, USA.

106. Brockington, D., Fortress Conservation: The Preservation of the Mkomazi Game Reserve, Tanzania. 2002: Indiana University Press.

107. Kepe, T., Globalization, Science, and the Making of an Environmental Discourse on the Wild Coast, South Africa. Environment and Planning A: Economy and Space, 2014. 46(9): p. 2143-2159.

108. Cavanagh, C.J., T. Weldemichel, and T.A. Benjaminsen, Gentrifying the African Landscape: The Performance and Powers of for-Profit Conservation on Southern Kenya's Conservancy Frontier. Annals of the American Association of Geographers, 2020. 110(5): p. 1594-1612.

109. Counsell, S., TheCongo'sNouabalé-Ndoki National Park: How Indigenous Lands Became an Emblem of Rooseveltian "Wilderness Conservation"in Africa, in Cornered by Protected Areas, J. Alcorn and A. Molnar, Editors. 2018, The Rights and Resources Initiative: Online.

110. Verweijen, J. and E. Marijnen, The counterinsurgency/conservation nexus: guerrilla livelihoods and the dynamics of conflict and violence in the Virunga National Park, Democratic Republic of the Congo. The Journal of Peasant Studies, 2018. 45(2): p. 300-320.

111. Dutta, A., Forest becomes frontline: Conservation and counter-insurgency in a space of violent conflict in Assam, Northeast India. Political Geography, 2020. 77: p. 102117.

112. Shrestha, Y. and R. Lapeyre, Modern Wildlife Monitoring Technologies: Conservationists versus Communities? A Case Study: The Terai-Arc Landscape, Nepal. Conservation and Society, 2018. 16(1): p. 91-101.

113. Büscher, B., et al., Towards a Synthesized Critique of Neoliberal Biodiversity Conservation. Capitalism Nature Socialism, 2012. 23:2: p. 4-30.

114. Mollett, S. and T. Kepe, Land Rights, Biodiversity Conservation and Justice: Rethinking Parks and People. 2018: Taylor \& Francis.

115. Dunlap, A. and S. Sullivan, A faultline in neoliberal environmental governance scholarship? Or, why accumulation-byalienation matters. Environment and Planning E: Nature and Space, 2020. 3(2): p. 552-579.

116. Fairhead, J., M. Leach, and I. Scoones, Green Grabbing: a new appropriation of nature? The Journal of Peasant Studies, 2012. 39(2): p. 237-261.

117. Segura Warnholtz, G., A.A. Molnar, and N. Ahuja, Forest communities in control: are governments and donors prepared to help them thrive? International Forestry Review, 2020. 22(1): p. 17-28.

118. Newton, P., et al., The Number and Spatial Distribution of Forest-Proximate People Globally. One Earth, 2020. 3(3): p. 363370.

119. Avila Martin, E., et al., Wild meat hunting and use by sedentarised Baka Pygmies in southeastern Cameroon. PeerJ, 2020. 8: p. e9906.

120. Duffy, R., et al., Toward a new understanding of the links between poverty and illegal wildlife hunting. Conserv Biol, 2016. 30(1): p. 14-22.

121. Duffy, R., et al., The militarization of anti-poaching: undermining long term goals? Environmental Conservation, 2015. 42(4): p. 345-348. 
122. Massé, F. and E. Lunstrum, Accumulation by securitization: Commercial poaching, neoliberal conservation, and the creation of new wildlife frontiers. Geoforum, 2016. 69: p. 227-237.

123. Dinerstein, E., et al., A "Global Safety Net" to reverse biodiversity loss and stabilize Earth's climate. Science Advances, 2020. 6(36): p. eabb2824.

124. Sobrevila, C., The Role of Indigenous Peoples in Biodiversity Conservation: The Natural but Often Forgotten Partners. The World Bank, Washington DC. , 2008.

125. O'Bryan, C.J., et al., The importance of indigenous peoples' lands for the conservation of terrestrial mammals. Conserv Biol, 2020. $\mathrm{n} / \mathrm{a}(\mathrm{n} / \mathrm{a})$.

126. CBD/SBSTTA/22/L.2.

127. Koot, S. and R. Hitchcock, In the way: perpetuating land dispossession of the indigenous Hail/om and the collective action law suit for Etosha National Park and Mangetti West, Namibia. Nomadic Peoples, 2019. 23: p. 55-77.

128. Rozzi, R., et al., From Biocultural Homogenization to Biocultural Conservation. 2019: Springer International Publishing.

129. Rozzi, R., Biocultural Ethics: Recovering the Vital Links between the Inhabitants, Their Habits, and Habitats. Environmental ethics, 2012. 34: p. 27-50.

130. Nepstad, D., et al., Inhibition of Amazon deforestation and fire by parks and indigenous lands. Conserv Biol, 2006. 20(1): p. 65-73.

131. Miteva, D.A., et al., The role of property rights in shaping the effectiveness of protected areas and resisting forest loss in the Yucatan Peninsula. PLOS ONE, 2019. 14(5): p. e0215820.

132. Schleicher, J., et al., Conservation performance of different conservation governance regimes in the Peruvian Amazon. Scientific Reports, 2017. 7(1): p. 11318.

133. García Latorre, J., Avoiding Deforestation and the Environmentalism of the Poor, in Participatory Biodiversity Conservation: Concepts, Experiences, and Perspectives, C. Baldauf, Editor. 2020, Springer International Publishing: Cham. p. 185-209.

134. Blackman, A., et al., Titling indigenous communities protects forests in the Peruvian Amazon. Proc Natl Acad Sci U S A, 2017. 114(16): p. 4123-4128.

135. Baragwanath, K. and E. Bayi, Collective property rights reduce deforestation in the Brazilian Amazon. Proc Natl Acad Sci U S A, 2020: p. 201917874.

136. Nolte, C., et al., Governance regime and location influence avoided deforestation success of protected areas in the Brazilian Amazon. Proc Natl Acad Sci U S A, 2013. 110(13): p. 4956-61.

137. Devine, J.A., et al., Drug trafficking, cattle ranching and Land use and Land cover change in Guatemala's Maya Biosphere Reserve. Land Use Policy, 2020. 95: p. 104578.

138. Wehkamp, J., et al., Governance and deforestation - a meta-analysis in economics. Ecological Economics, 2018. 144: p. 214-227.

139. Stevens, C., et al., Securing rights, combating climate change: How strengthening community forest rights mitigates climate change. 2014, World Resource Institute: World Resource Institute. Washington D.C.

140. Walker, W.S., et al., The role of forest conversion, degradation, and disturbance in the carbon dynamics of Amazon indigenous territories and protected areas. Proceedings of the National Academy of Sciences, 2020. 117(6): p. 3015-3025.

141. Rights and Resources Initiative, A Global Baseline of Carbon Storgae in Collecitve Lands: Indigenous and Local Communities Contributions to Climate Change. 2018, Rights and Resources Initiative: Rights and Resources Initiative.

142. Schuster, R., et al., Vertebrate biodiversity on indigenous-managed lands in Australia, Brazil, and Canada equals that in protected areas. Environmental Science \& Policy, 2019. 101: p. 1-6.

143. Corrigan, C., et al., Quantifying the contribution to biodiversity conservation of protected areas governed by indigenous peoples and local communities. Biological Conservation, 2018. 227: p. 403-412.

144. Campos-Silva, J.V., et al., Community-Based Management of Amazonian Biodiversity Assets, in Participatory Biodiversity Conservation: Concepts, Experiences, and Perspectives, C. Baldauf, Editor. 2020, Springer International Publishing: Cham. p. 99-111.

145. Rights and Resources Initiative, Securing Community Land Rights: Priorities and Opportunities to Advance Climate and Sustainable Development Goals. 2017, Rights and Resources Initiative: Washington, DC.

146. Amazon Geo-Referenced Socio-Environmental Information Network (RAISG), "Amazonia 2016 - Protected areas and indigenous territories/deforestation 2000-2015". 2016.

147. Global Witness, Power to the People? How Companies are Exploiting Community Forestry in Liberia. 2018, Global Witness: London.

148. Jusys, T., Changing patterns in deforestation avoidance by different protection types in the Brazilian Amazon. PLOS ONE, 2018. 13(4): p. e0195900.

149. Schwartzman, S., et al., The natural and social history of the indigenous lands and protected areas corridor of the Xingu River basin. Philosophical Transactions of the Royal Society B: Biological Sciences, 2013. 368(1619): p. 20120164.

150. Soares-Filho, B., et al., Role of Brazilian Amazon protected areas in climate change mitigation. Proceedings of the National Academy of Sciences, 2010. 107(24): p. 10821-10826.

151. Oliveira, P.J.C., et al., Land-Use Allocation Protects the Peruvian Amazon. Science, 2007. 317(5842): p. $1233-1236$.

152. F. Seymour, T. La Vina, and K. Hite, Evidence linking community- level tenure and forest condition: An annotated bibliography. Climate and Land Use Alliance. 2014: Climate and Land Use Alliance. [online]. 
153. Gray, E., et al., The economic costs and benefits of securing community forest tenure: evidence from Brazil and Guatemala. 2015, World Resources Institute: Washington, DC.

154. Allan, J.R., et al., The Extraordinary Value of Wilderness Areas in the Anthropocene, in Encyclopedia of the World's Biomes. 2020. p. 158-168.

155. Asiyanbi, A.P., A political ecology of REDD+: Property rights, militarised protectionism, and carbonised exclusion in Cross River. Geoforum, 2016. 77: p. 146-156.

156. Lunstrum, E., Capitalism, Wealth, and Conservation in the Age of Security: The Vitalization of the State. Annals of the American Association of Geographers, 2018. 108(4): p. 1022-1037.

157. Wilson, L. and R. Boratto, Conservation, wildlife crime, and tough-on-crime policies: Lessons from the criminological literature. Biological Conservation, 2020. 251: p. 108810.

158. Anaya, F.C. and M.M. Espírito-Santo, Protected areas and territorial exclusion of traditional communities: analyzing the social impacts of environmental compensation strategies in Brazil. Ecology and Society, 2018. 23(1).

159. Busscher, N., C. Parra, and F. Vanclay, Land grabbing within a protected area: The experience of local communities with conservation and forestry activities in Los Esteros del Iberá, Argentina. Land Use Policy, 2018. 78: p. 572-582.

160. McLain, R., et al., Toward a tenure-responsive approach to forest landscape restoration: A proposed tenure diagnostic for assessing restoration opportunities. Land Use Policy, 2018.

161. Erbaugh, J.T., et al., Global forest restoration and the importance of prioritizing local communities. Nature Ecology \& Evolution, 2020.

162. Cooney, R., et al., From Poachers to Protectors: Engaging Local Communities in Solutions to Illegal Wildlife Trade. Conservation Letters, 2017. 10(3): p. 367-374.

163. Cooney, R. and D.W.S. Challender, Engaging local communities in responses to illegal trade in pangolins: who, why and how?, in Pangolins, D.W.S. Challender, H.C. Nash, and C. Waterman, Editors. 2020, Academic Press. p. 369-383.

164. Zafra-Calvo, N. and J. Geldmann, Protected areas to deliver biodiversity need management effectiveness and equity. Global Ecology and Conservation, 2020. 22: p. e01026.

165. Mackey, B. and D. Claudie, Points of Contact: Integrating Traditional and Scientific Knowledge for Biocultural Conservation. Environmental Ethics, 2015. 37: p. 341-357.

166. Pretty, J., et al., The Intersections of Biological Diversity and Cultural Diversity: Towards Integration. Conservation and Society, 2009. 7(2): p. 100-112.

167. Gorenflo, L.J., et al., Co-occurrence of linguistic and biological diversity in biodiversity hotspots and high biodiversity wilderness areas. Proc Natl Acad Sci U S A, 2012. 109(21): p. 8032-7.

168. Lombardo, U., et al., Early Holocene crop cultivation and landscape modification in Amazonia. Nature, 2020. 581(7807): p. 190-193.

169. Stephens, L., et al., Archaeological assessment reveals Earth's early transformation through land use. Science, 2019. 365(6456): p. 897-902.

170. Albó, X., Suma Qamaña or Living Well Together: A Contribution to Biocultural Conservation. 2018. p. $333-342$.

171. Buscher, B. and R. Fletcher, The Conservation Revolution: Radical Ideas for Saving Nature Beyond the Anthropocene. 2020: Verso Books.

172. Büscher, B. and R. Fletcher, Towards Convivial Conservation. Conservation \& Society, 2019. 17(3): p. 283-296.

173. Freeman, M., Human Rights: An Interdisciplinary Approach. 2011: Wiley.

174. Short, D., Redefining Genocide: Settler Colonialism, Social Death and Ecocide. 2016: Zed Books.

175. Knight, R., The Challenge of Protecting Community Land Rights: An Investigation into Community Responses to Requests for Land and Resources. 2019, Namati: Washington D.C.

176. Atuahene, B., From Reparation to Restoration: Moving Beyond Restoring Property Rights to Restoring Political and Economic Visibility. Southern Methodist University Law Review, 2007. 60(4).

177. Büscher, B., et al., Half-Earth or Whole Earth? Radical ideas for conservation, and their implications. Oryx, 2017. 51(3): p. 407-410.

178. Vallejos, P.Q., et al., Undermining Rights: Indigenous Lands and Mining in the Amazon. 2020, World Resource Institute and Amazon Geo-Referenced Socio-Environmental Information Network: World Resource Institute and Amazon GeoReferenced Socio-Environmental Information Network. Washington D.C.

179. Rights and Resources Initiative, The Opportunity Framework: Identifying Opportunities to Invest in Securing Collective Tenure Rights in the Forest Areas of Low and Lower Middle Income Countries. 2020, Rights and Resources Initiative: Washington D.C.

180. Kashwan, P., Democracy in the Woods: Environmental Conservation and Social Justice in India, Tanzania, and Mexico. 2017: Oxford University Press.

181. Ostrom, E., Governing the Commons: The Evolution of Institutions for Collective Action. 2015: Cambridge University Press.

182. Global Witness, Defending Tomorrow. 2020, Global Witness: London, UK.

183. Persha, L., A. Agrawal, and A. Chhatre, Social and ecological synergy: local rulemaking, forest livelihoods, and biodiversity conservation. Science, 2011. 331(6024): p. 1606-8.

184. UNEP-WCMC, User Manual for the World Database on Protected Areas and world database on other effective area-based conservation measures:1.6. 2019, UNEP-WCMC: Cambridge, UK. 
185. IUCN, A Global Standard for the Identification of Key Biodiversity Areas. 2016: Gland, Switzerland.

186. Venter, O., et al., Targeting Global Protected Area Expansion for Imperiled Biodiversity. PLOS Biology, 2014. 12(6): p. e1001891.

187. Rodrigues, A., et al., Effectiveness of the global protected area NETWORK in representing species diversity. Nature, 2004. 428: p. 640-3.

188. Butchart, S.H.M., et al., Shortfalls and Solutions for Meeting National and Global Conservation Area Targets. Conservation Letters, 2015. 8(5): p. 329-337.

189. Olson, D.M., et al., Terrestrial Ecoregions of the World: A New Map of Life on Earth: A new global map of terrestrial ecoregions provides an innovative tool for conserving biodiversity. BioScience, 2001. 51(11): p. 933-938.

190. Di Marco, M., et al., Wilderness areas halve the extinction risk of terrestrial biodiversity. Nature, 2019. 573(7775): p. $582-585$.

191. Naidoo, R. and T. Iwamura, Global-scale mapping of economic benefits from agricultural lands: Implications for conservation priorities. Biological Conservation, 2007. 140(1-2): p. 40-49.

192. Maskun, M., Legal Protection Of Mangrove Forests: From Community Consensus To Written Law. 2019. 236-247.

193. Van Lavieren, H., et al., Securing the Future of Mangroves. A Policy Brief. 2012.

194. Allison, E., et al., Rights-based Fisheries Governance: From fishing rights to human rights. Fish and Fisheries, 2011. 13: p. 1429.

195. Teh, L.C.L., et al., The role of human rights in implementing socially responsible seafood. PLOS ONE, 2019. 14(1): p. e0210241.

196. Schleicher, J., et al., Protecting half of the planet could directly affect over one billion people. Nature Sustainability, 2019. 2(12): p. 1094-1096.

197. Allan, J.R., et al., Gaps and opportunities for the World Heritage Convention to contribute to global wilderness conservation. Conservation Biology, 2018. 32(1): p. 116-126.

198. Fabricius, C., et al., Conservation and mobile indigenous peoples: displacement, forced settlement and sustainable development. null. Vol. null. 2002. null.

199. ESRI, 'ArcGIS Desktop: Release 10.5, CA: Environmental Systems Research Institute.' Global Administrative Areas (2020). GADM database of Global Administrative Areas, version 2.0. 2019.

200. The United Nations Department of Economic and Social Affairs Population Division, Household Size and Composition Around the World 2017 - Data Booklet (ST/ESA/ SER.AV405). 2017.

201. Hansen, M.C., et al., High-resolution global maps of 21st-century forest cover change. Science, 2013. 342(6160): p. 850-3.

202. Puyravaud, J., Standardizing the calculation of the annual rate of deforestation. Forest Ecology and Management, 2003. 177: p. 593-596.

203. Land Mark. LandMark: Global Platform of Indigenous and Community Lands. 2020 [cited 2020; Available from: http://www.landmarkmap.org/.

204. Global Forest Watch. Global Forest Watch - Map. 2014 [cited 2020; Available from: https://www.globalforestwatch.org.

' For RRI, the term 'Indigenous Peoples' follows the definition or 'statement of coverage' contained in the International Labor Organization Convention on Indigenous and Tribal Peoples in Independent Countries. Therefore, it includes:

- Peoples who identify themselves as 'indigenous.'

- Tribal peoples whose social, cultural, and economic conditions distinguish them from other sections of the national community, and whose status is regulated wholly or partially by their own customs or traditions or by special laws or regulations.

- Traditional peoples not necessarily called indigenous or tribal but who share the same characteristics of social, cultural, and economic conditions that distinguish them from other sections of the national community, whose status is regulated wholly or partially by their own customs or traditions, and whose livelihoods are closely connected to ecosystems and their goods and services. While RRI recognizes that all people should enjoy equal rights and respect regardless of identity, it is strategically important to distinguish Indigenous Peoples from other stakeholders. They have a distinct set of rights linked to their social, political and economic situation as a result of their ancestry and stewardship of lands and resources that are vital to their well-being.

ii Recognizing that local communities are not formally defined under international law, RRI considers that they encompass communities that do not self-identify as Indigenous but who share similar characteristics of social, cultural, and economic conditions that distinguish them from other sections of the national community, whose status is regulated wholly or partially by their own customs or traditions, who have long standing, culturally constitutive relations to lands and resources, and whose rights are held collectively.

iii As per the Declaration of Santiago of 2000, the States of the Americas defined Afro-descendant as "a person of African origin who lives in the Americas and in the region of the African Diaspora as a result of slavery, who has been denied the exercise of their fundamental rights." (See: The Durban Conference and Program of Action; The International Decade for People of African Descent. https://www.un.org/en/durbanreview2009/pdf/DDPA full text.pdf). In Latin America and the Caribbean, constitutional 
and legal recognition of Afro-descendants' collective tenure rights is based on their special cultural, ethnic, and spiritual relationship with land. Colombia, Brazil, Ecuador, Nicaragua, and Honduras, including others, have such legislation. iv Zero draft of the CBD: [By 2030,] protect [at least [30\%] of land and sea areas] through [effectively and equitably managed] protected areas and other effective area-based conservation measures, [in accordance with the principles of ecological representativity and connectivity for protected area systems, while including] at least [60\%] of [sites of particular importance for biodiversity] and with at least [10\%] [of land and sea areas] under strict protection[, through zonation, where appropriate]. ${ }^{\vee}$ CBD/COP/DEC/14/8, Annex III, Section A, paragraph (h) "Recognition of other effective area-based conservation measures should be supported by measures to enhance the governance capacity of their legitimate authorities and secure their positive and sustained outcomes for biodiversity, including, inter alia, policy frameworks and regulations to prevent and respond to threats;" and (i) "Recognition of other effective area-based conservation measures in areas within the territories of Indigenous Peoples and local communities should be on the basis of self-identification and with their free, prior and informed consent, as appropriate, and consistent with national policies, regulations and circumstances, and applicable international obligations." vi "For the current 2021 fiscal year, low-income economies are defined as those with a GNI per capita, calculated using the World Bank Atlas method, of $\$ 1,035$ or less in 2019; lower middle-income economies are those with a GNI per capita between $\$ 1,036$ and $\$ 4,045$; upper middle-income economies are those with a GNI per capita between $\$ 4,046$ and $\$ 12,535$; high-income economies are those with a GNI per capita of \$12,536 or more." Quoted from: World Bank Country and Lending Groups - List of economies database. 2020. Washington, DC: The World Bank Group

vii See: The Durban Conference and Program of Action; The International Decade for People of African Descent

https://www.un.org/en/durbanreview2009/pdf/DDPA full text.pdf

viii While marine areas also feature in the targets of the CBD analysis the people you use water resources is beyond the scope of this research.

ix UNEP-WCMC and IUCN, Protected Planet: The World Database on Protected Areas (WDPA). 2020: Cambridge, UK: UNEP-WCMC and IUCN. (July 2020 version)

× The World Banks' OP 4.12 has been referenced for involuntary resettlement practices which cover the direct economic and social impacts resulting from investments caused by "(a) the involuntary taking of land resulting in (i) relocation or loss of shelter; (ii) loss of assets or access to assets; or (iii) loss of income sources or means of livelihood, whether or not the affected persons must move to another location; or (b) the involuntary restriction of access to legally designated parks and protected areas resulting in adverse impacts on the livelihoods of the displaced persons". Project-affected persons who are entitled to compensation due to the social and economic impacts of projects can subsequently be entitled to receiving compensation. The "unit of entitlement" can be an individual, a family or household, or a community.

${ }^{x i}$ Investments were calculated based on the labor and cash invested by communities, from their resources, that were spent on conservation activities such as fire protection and management, restoration and rehabilitation, forest management, mapping, patrolling and policing and cataloguing biodiversity (see: Tauli-Corpuz, et al., 2018).

xii For a growing body of successful case studies and resources, please view the 'People not Poaching' website. https://www.peoplenotpoaching.org

xiii Biocultural conservation, integrating Indigenous and Local Knowledge in conservation strategies, therefore entails the conservation, revitalisation, and integration of traditional knowledge systems through inclusive decision-making and the active participation of communities.

xiv For instance, in historically communal lands of the Maasai Mara, the formation of "secure" private tenure rights and the cooption of environmental crisis narratives enable commercial eco-tourism businesses to appropriate lands through "legal" means that still perpetuate inequality. See Cavanagh et al., 2020.

${ }^{x v}$ The International Land and Forest Tenure Facility is a non-profit organization that provides grants to secure the rights of Indigenous Peoples and local communities to their lands and forests, thereby strengthening their communities and reducing global climate change and poverty in forest areas in the world https://thetenurefacility.org/. 